Atmos. Chem. Phys., 18, 10237-10254, 2018

https://doi.org/10.5194/acp-18-10237-2018

(C) Author(s) 2018. This work is distributed under

the Creative Commons Attribution 4.0 License.

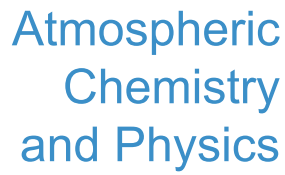

(c) (i)

\title{
High gas-phase mixing ratios of formic and acetic acid in the High Arctic
}

\author{
Emma L. Mungall ${ }^{1}$, Jonathan P. D. Abbatt ${ }^{1}$, Jeremy J. B. Wentzell ${ }^{2}$, Gregory R. Wentworth ${ }^{1,3}$, Jennifer G. Murphy ${ }^{1}$, \\ Daniel Kunkel $^{4}$, Ellen Gute ${ }^{1}$, David W. Tarasick ${ }^{2}$, Sangeeta Sharma ${ }^{2}$, Christopher J. Cox ${ }^{5,6}$, Taneil Uttal ${ }^{5}$, and \\ John Liggio ${ }^{2}$ \\ ${ }^{1}$ Department of Chemistry, University of Toronto, Toronto, Canada \\ ${ }^{2}$ Air Quality Processes Research Section, Environment and Climate Change Canada, Toronto, Ontario, Canada \\ ${ }^{3}$ Environmental Monitoring and Science Division, Alberta Environment and Parks, Edmonton, Alberta, Canada \\ ${ }^{4}$ Institute for Atmospheric Physics, Johannes Gutenberg University of Mainz, Mainz, Germany \\ ${ }^{5}$ NOAA Earth Systems Research Laboratory (ESRL), Physical Sciences Division (PSD), Boulder, CO, USA \\ ${ }^{6}$ Cooperative Institute for Research in Environmental Sciences (CIRES), Boulder, CO, USA
}

Correspondence: Jon Abbatt (jabbatt@ chem.utoronto.ca)

Received: 21 January 2018 - Discussion started: 23 January 2018

Revised: 5 July 2018 - Accepted: 6 July 2018 - Published: 18 July 2018

\begin{abstract}
Formic and acetic acid are ubiquitous and abundant in the Earth's atmosphere and are important contributors to cloud water acidity, especially in remote regions. Their global sources are not well understood, as evidenced by the inability of models to reproduce the magnitude of measured mixing ratios, particularly at high northern latitudes. The scarcity of measurements at those latitudes is also a hindrance to understanding these acids and their sources. Here, we present ground-based gas-phase measurements of formic acid (FA) and acetic acid (AA) in the Canadian Arctic collected at $0.5 \mathrm{~Hz}$ with a high-resolution chemical ionization time-of-flight mass spectrometer using the iodide reagent ion (iodide HR-ToF-CIMS, Aerodyne). This study was conducted at Alert, Nunavut, in the early summer of 2016. FA and AA mixing ratios for this period show high temporal variability and occasional excursions to very high values (up to 11 and $40 \mathrm{ppbv}$ respectively). High levels of FA and AA were observed under two very different conditions: under overcast, cold conditions during which physical equilibrium partitioning should not favor their emission, and during warm and sunny periods. During the latter, sunny periods, the FA and AA mixing ratios also displayed diurnal cycles in keeping with a photochemical source near the ground. These observations highlight the complexity of the sources of FA and AA, and suggest that current chemical transport model im-
\end{abstract}

plementations of the sources of FA and AA in the Arctic may be incomplete.

\section{Introduction}

Formic acid (FA) and acetic acid (AA) are ubiquitous and abundant in the troposphere and are major contributors to cloud water acidity in remote regions (Paulot et al., 2011). Cloud water serves as an important atmospheric chemical reactor (Lelieveld and Crutzen, 1991). As many chemical reactions depend strongly on $\mathrm{pH}$, cloud water acidity is relevant to the formation of secondary organic aerosol as well as to the processing of other forms of atmospheric particulate matter (Ervens et al., 2011). FA and AA have been measured in a wide variety of environments, both urban and remote, from the poles to the Amazon to the largest cities in North America. FA and AA have many different sources, although the relative contributions of those sources depend on the location, and not every source will be relevant in every location. The sources of FA and AA include secondary photochemical production from both anthropogenic and biogenic precursors (Yuan et al., 2015; Liggio et al., 2017); direct emissions from plants (Kesselmeier et al., 1998; Kuhn et al., 2002), soils (Sanhueza and Andreae, 1991), and biomass burning (Veres et al., 2010; Ito and Penner, 2004); direct emissions 
from fossil fuel combustion (Crisp et al., 2014; Kawamura et al., 1985; Liggio et al., 2017); and photochemical production in snowpacks (Dibb and Arsenault, 2002). FA and AA tend to decrease with altitude (Millet et al., 2015; Paulot et al., 2011), and aircraft studies (e.g., Jones et al., 2014; Le Breton et al., 2012) generally find lower mixing ratios than ground-based studies (e.g., Schobesberger et al., 2016; Talbot et al., 1988), suggesting that the major sources of these compounds may be at or near the surface.

While the balance between sources remains uncertain both globally and regionally, a recent bottom-up estimate of the global FA and AA budget concluded that photochemical production from biogenic precursors was by far the largest source, with the remaining sources each contributing an order of magnitude less (Paulot et al., 2011). Furthermore, two pieces of evidence indicate that anthropogenic sources, whether primary or secondary, probably do not account for the majority of atmospheric FA and AA. First, radiocarbon analysis of FA has found it to be mostly composed of modern carbon (Glasius et al., 2001), particularly in non-urban areas. Second, analyses of ice cores from the Greenland ice sheet spanning the last 10000 years have found concentrations of formate and acetate similar to modern snowpack concentrations, with lower values during the last ice age, suggesting the importance of biogenic contributions from North America (Legrand and De Angelis, 1995).

In contrast to their sources, the sinks of FA and AA are thought to be fairly well constrained. The reactivity of these acids towards the hydroxyl radical is low, while their Henry's law constants are high, such that their main sink in the boundary layer is deposition, both wet and dry (Paulot et al., 2011). Once taken up into water, FA and AA are degraded both photochemically and microbially. FA and AA can also be taken up onto dust and may undergo heterogeneous degradation there. Gas-to-particle partitioning is not considered an important sink of FA and AA as particle-phase concentrations are generally only a few percent of gas-phase mixing ratios (Liu et al., 2012; Chebbi and Carlier, 1996; Baboukas et al., 2000). Considering the various sinks, the average global lifetimes of FA and AA in the boundary layer have been estimated at 1-2 days (Paulot et al., 2011), although the lifetimes are of course highly dependent on the likelihood of deposition and thus, for example, on how dry or wet the environment is. Despite all of this information, chemical transport models and box models persistently underestimate the FA and AA mixing ratios measured by both remote sensing and in situ techniques (Paulot et al., 2011; Millet et al., 2015; Schobesberger et al., 2016; von Kuhlmann, 2003; Liggio et al., 2017; Yuan et al., 2015; Stavrakou et al., 2012).

Several explanations for the discrepancy between measurements and models have been suggested, including an unconstrained soil source (Schobesberger et al., 2016), a direct biogenic source that exceeds prior expectations (Stavrakou et al., 2012; Schobesberger et al., 2016; Millet et al., 2015), and as-yet-unknown secondary chemistry (Liggio et al.,
2017; Paulot et al., 2011; Millet et al., 2015). These unexplained mixing ratios are often high (on the order of a few ppbv), and the model-measurement discrepancies are particularly large in the Arctic and northern mid-latitudes (Paulot et al., 2011; Schobesberger et al., 2016; Stavrakou et al., 2012). Despite in situ measurements at high latitudes showing significant amounts of FA and AA (high pptv to low ppbv levels; Talbot et al., 1992; Klemm et al., 1994; Dibb and Arsenault, 2002; Jones et al., 2014; Viatte et al., 2014), the modeled concentrations for both acids in this region are very low. While some of this discrepancy may be due to a failure of the models to capture the persistent stable stratification which characterizes the Arctic boundary layer (Tjernström, 2007; Willis et al., 2017), problems with the representation of precursor emissions, chemical production, or emission processes are also likely contributors. Underestimating FA and AA mixing ratios is problematic because of the important role FA and AA are expected to play in determining rainwater acidity in the Arctic and other remote environments.

The existing high-latitude studies are widely separated in time and space. In addition to their sporadic nature, none of these studies report a continuous high-temporal-resolution time series measured at a ground site. Such measurements are valuable for isolating competing atmospheric processes. Here, we present measurements of FA and AA made with an iodide HR-ToF-CIMS over 3 weeks spanning the transition from late spring to midsummer (18 June-13 July 2016) at Alert, Nunavut, as well as measurements of formate and acetate in precipitation over the same time period. Given the scarcity of data in the region, this study constitutes an important addition to our understanding of the global distribution of these compounds. We discuss the possible sources of the measured FA and AA. Since these acids have frequently been shown to share similar sources and are generally discussed together (e.g., Paulot et al., 2011; Baboukas et al., 2000), and in this work FA and AA are well correlated $\left(R^{2}=0.63\right)$, we do not separate them as we attempt to place our observations within the context of the current understanding of their sources.

\section{Methods}

\subsection{Field site}

The sampling campaign took place from 18 June to 13 July 2016 at the Dr. Neil Trivett Global Atmospheric Watch Observatory (GAW lab) at Alert, Nunavut, located near the northern tip of Ellesmere Island $\left(82^{\circ} 27^{\prime} \mathrm{N}\right.$, $62^{\circ} 30^{\prime} \mathrm{W} ; 187 \mathrm{~m}$ elevation). The GAW lab is located $7 \mathrm{~km}$ southwest of Canadian Forces Station Alert (relative locations of the station and the laboratory are shown in Fig. 1a). The GAW lab experienced $24 \mathrm{~h}$ of sunlight throughout the campaign. 

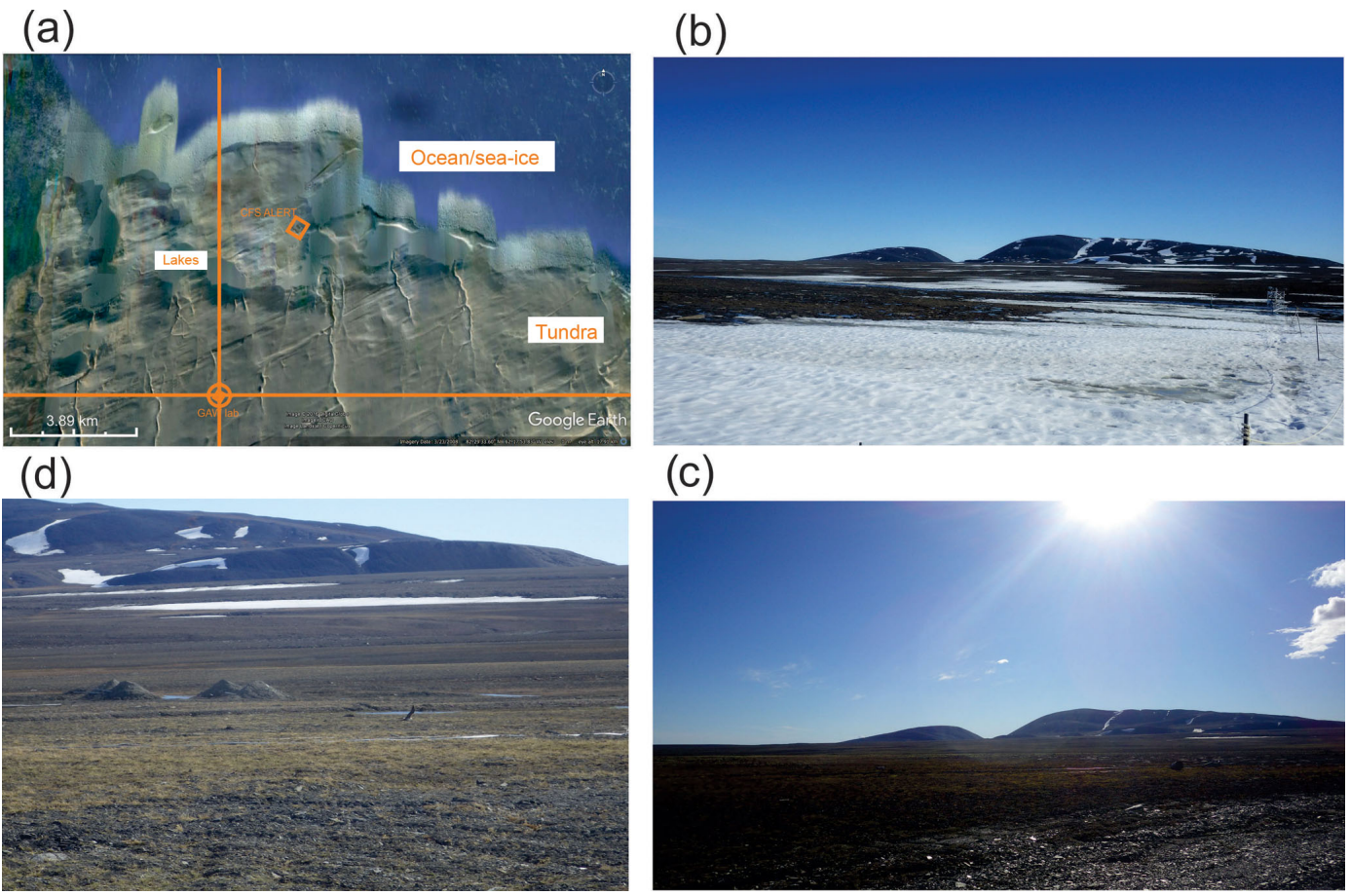

Figure 1. Photographs showing important aspects of the sampling environment. (a) Google Earth photograph showing CFS Alert and the GAW lab. (b) Photograph from the GAW lab in late June 2017 showing the snowpack remnants. (c) Photograph from the GAW lab in early July 2017 showing that all the snow had melted. (d) Characteristic close-up of the surrounding tundra showing the large percentage of bare soil.

\subsection{Gas-phase measurements}

FA and AA were measured using a high-resolution timeof-flight chemical ionization mass spectrometer (HR-ToFCIMS, Aerodyne) with the iodide reagent ion. The iodide CIMS ionizes analyte molecules through a ligand-exchange reaction with the $\mathrm{I}_{2}^{-} \cdot \mathrm{H}_{2} \mathrm{O}$ ion, leading to the formation of a charged adduct that is detected by the mass spectrometer (Lee et al., 2014). The iodide CIMS was located in a wooden shed set up on scaffolding outside the main laboratory building. A $3 / 8$ in. outer diameter Teflon inlet (length $6 \mathrm{~m}$ ) sampled from a height of $4.5 \mathrm{~m}$ above the ground, where it was secured to the second level of the scaffolding. A bypass flow of $25 \mathrm{~L} \mathrm{~min}^{-1}$, controlled by a critical orifice, passed through this line, from which the CIMS subsampled at the rate of $2.3 \mathrm{~L} \mathrm{~min}^{-1}$ (also controlled by a critical orifice). These parameters resulted in a residence time of air in the inlet of $\sim 1 \mathrm{~s}$. The iodide reagent ion was supplied by a flow of nitrogen from a nitrogen generator (Parker Balston UHP3200CN2) passing over a permeation tube containing methyl iodide. The permeation tube was contained within a permeation oven and the temperature of the outer surface of the permeation oven was maintained at $40^{\circ} \mathrm{C}$ (the temperature in the center of the permeation oven would have been lower, but was not measured). The methyl-iodide-containing nitrogen stream passed through a sealed ${ }^{210}$ Po radioactive source, creating $\mathrm{I}^{-} \cdot \mathrm{H}_{2} \mathrm{O}$ ion clusters which reacted with the molecules of interest in the ion-molecule reaction region (IMR) of the mass spectrometer. Analytes are detected as their $\mathrm{I}^{-}$clusters. Backgrounds were collected for $2 \mathrm{~min}$ of every hour by overflowing the mass spectrometer inlet (downstream of the Teflon inlet line) with the exhaust flow from the bypass line, which has been passed over a Pt catalyst heated to $350^{\circ} \mathrm{C}$, followed by sodium bicarbonate and activated carbon cartridges in series. The instrumental stability was monitored by constant addition of ${ }^{13} \mathrm{C}$ labeled propionic acid. The pressure in the IMR was controlled via a flowcontroller-mediated leak in the line leading from the IMR to the pump. A relative humidity and temperature sensor was installed in this line to monitor the absolute humidity in the IMR.

Calibrations were carried out after the campaign using the Ionicon liquid calibration unit (LCU). Known mixing ratios of FA and AA at known absolute humidities were provided to the instrument by the LCU. The humidity dependence of the individual compound sensitivities was determined, as water vapor can cluster preferentially with the iodide ions, leading to either an increase or a decrease in the ionization efficiency of analyte molecules depending on the identity of the molecule. These calibration data were fit using a multiple linear regression and applied to the ambient data as a function of the absolute humidity measured in the flow exiting 
the IMR to correct for the water vapor dependence. Details concerning the calibration calculations may be found in the Supplement (Sect. S1). The limits of detection were, on average, $0.3 \mathrm{ppbv}$ for FA and $0.7 \mathrm{ppbv}$ for AA. The limits of detection were calculated as 3 times the standard deviation in the background signal averaged over a $5 \mathrm{~min}$ period, and varied by less than $10 \%$ over the entire campaign. The calibration uncertainty (determined as the range between the two calibration experiments) was $15 \%$ for FA and $50 \%$ for AA. Due to the instrumental response being much higher for FA than for AA, the FA signal had a much higher signal-to-noise ratio than did the AA signal, resulting in the high-frequency variance visible in the AA time series.

\subsection{Precipitation measurements}

Bulk precipitation samples were collected on the roof of the GAW lab using three adjacent collectors consisting of a polypropylene funnel $(0.1 \mathrm{~m}$ diameter $)$ secured to a polypropylene bottle ( $125 \mathrm{~mL}$ total volume). Bulk collectors were rinsed three times each with deionized water and air dried prior to deployment. We assume the input of dry deposition to be negligible given the low particulate matter concentration throughout the study as well as the small diameter of the funnel mouth. Precipitation samples were collected at the end of each precipitation event or, if precipitation occurred overnight, at 08:30 (local time) the following morning. Samples were immediately frozen to prevent biodegradation (Vet et al., 2014) until analysis at the end of the campaign. Acetate and formate were quantified using an ion chromatograph (IC, Thermo Fisher Scientific) that was calibrated with a series of five aqueous standards prepared via serial dilution. A field blank was collected by rinsing each collector with $\sim 50 \mathrm{~mL}$ of deionized water. The volume-weighted IC signal of the field blank was subtracted from each sample. However, the field blank signals for formate and acetate were roughly a factor of 50 and 100 smaller, respectively, than the average precipitation sample. The $\mathrm{pH}$ of the samples was not measured. The $\mathrm{pH}$ of the precipitation was estimated using IC measurements of the major ions $\left(\mathrm{Na}^{+}, \mathrm{NH}_{4}^{+}, \mathrm{Cl}^{-}, \mathrm{NO}_{3}^{-}, \mathrm{SO}_{4}^{2-}\right)$ as $\mathrm{pH}=-\log \left(\sum\right.$ anions $-\sum$ cations $)$.

The duration of the sampled precipitation events was estimated using the images captured every minute by an upwardfacing camera (total sky imager TSI-440, Yankee Environmental Systems, Inc.). Precipitation is visible in these images as raindrops striking the lens (e.g., Fig. S7 in the Supplement), and the time that the rain stopped was identified as when the pattern of drops stopped changing. Precipitation amount was quantified by dividing the volume of each precipitation sample by the funnel footprint of the collectors (details in Supplement, Sect. S3.1).

\subsection{Ancillary data}

Aerosol particles were brought into the GAW lab from the ambient atmosphere via a $3 \mathrm{~m}$ long $10 \mathrm{~cm}$ inner diameter vertical manifold with a $\sim 1000 \mathrm{~L} \mathrm{~min}^{-1}$ flow rate. The particles were subsampled for individual instruments by stainless steel tubing from the center of the flow stream, about $30 \mathrm{~cm}$ up from the bottom of the manifold. The mean residence time of a particle in the sampling manifold before being detected by an instrument was $3 \mathrm{~s}$. The total particle counts greater than $4 \mathrm{~nm}$ were measured by a condensational particle counter (CPC, TSI 3772). Particle diameters from 20-500 nm were measured using a scanning mobility particle sizer (SMPS, TSI 3034). The SMPS was verified using monodisperse polystyrene latex and ammonium sulfate particles using a scanning electrical mobility spectrometer (SEMS, Brechtel Manufacturing Incorporated).

Wind speed and direction were measured by a wind sensor (Campbell Scientific, 05103-10), and dew point and temperature were measured by a Vaisala logger. All meteorological data are averaged to $5 \mathrm{~min}$ before saving by the Campbell Scientific data logger. Total downwelling shortwave radiation was measured at a Baseline Surface Radiation Network (BSRN; Ohmura et al., 1998) station, located approximately $100 \mathrm{~m}$ south of the GAW lab. In this work, downwelling shortwave radiation is represented as the sum of the measured diffuse and direct components as observed at a height of $2 \mathrm{~m}$ above the surface. The diffuse light was measured by a shaded Eppley Black \& White pyranometer (PSP) and the direct light was measured by an Eppley normal incidence pyrheliometer (NIP). The data were quality controlled following the method of Long and Shi (2008). The calibration uncertainty is $0.5-1 \%$ for the NIP and $1-2 \%$ for the PSP. Fractional sky cover was derived from the radiation measurements following (Long et al., 2006). Mixing height was estimated from radiosoundings deployed by the EC weather station at Alert twice-daily, at 00:00 and 12:00 UTC (07:00 and 19:00 local time). Further details on mixing height estimation may be found in Sect. S2.

\subsection{Soil data}

Soil temperature was monitored by two iButton temperature loggers (Maxim Integrated) placed at a depth of $10 \mathrm{~cm}$ within $25 \mathrm{~m}$ of the GAW lab. Soil cores were collected in triplicate from three separate sites in the surrounding area (up to $5 \mathrm{~km}$ away, one on 8 July 2016 and the other two on 15 July 2016) and analyzed according to Wentworth et al. (2014). After clearing any surface debris (i.e., vegetation, rocks, pebbles), $10 \mathrm{~cm}$ deep cores were retrieved using a PVC tube $(5.1 \mathrm{~cm}$ inner diameter) and hammer. Cores remained frozen until they were analyzed about 1 month later. Soil $\mathrm{pH}$ was measured in duplicate for each extract using a standard $\mathrm{pH}$ electrode (Orion Model 250A, Thermo Scientific) immersed in a 1:1 slurry of soil and deionized water. The $\mathrm{pH}$ electrode 

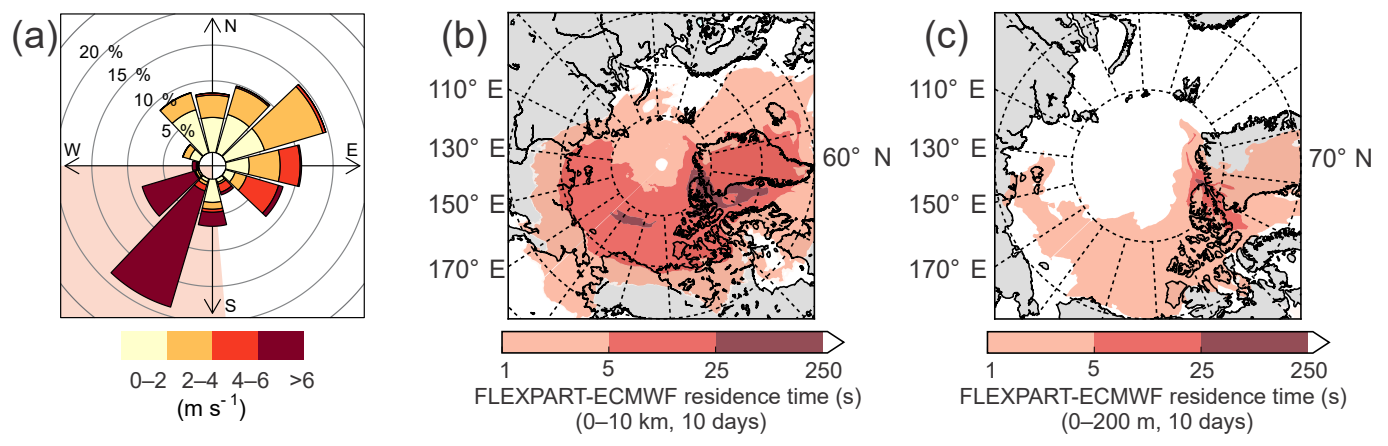

Figure 2. (a) Wind rose for the entire campaign. The shaded area shows the high wind speed regime (see text). (b) FLEXPART-ECMWF summed over the entire column $(0-10 \mathrm{~km})$, averaged over the entire campaign, and integrated 10 days back in time. That the darker colors are mostly restricted to the Arctic indicates that the air arriving at Alert had mostly spent at least the last 10 days within the Arctic circle. (c) FLEXPART-ECMWF summed over the lowest $200 \mathrm{~m}$, averaged over the entire campaign, and integrated 10 days back in time.

was triple-point calibrated with commercially available $\mathrm{pH}$ standards (4.01, 7.00, and 10.00).

\subsection{FLEXPART-ECMWF}

Air mass histories were computed using the Lagrangian FIEXible PARTicle dispersion (FLEXPART) model version 10.0 Stohl et al. (2005), which was driven by meteorological analysis fields from the European Centre for Medium-Range Weather Forecasts (ECMWF). For this study, non-interacting particles are released for $24 \mathrm{~h}$ and traced back for 10 days. Results were output every $6 \mathrm{~h}$ at six different altitude levels with upper level boundaries of 200,500,1000, 2000, 5000 m, and $10 \mathrm{~km}$. For use in this work, the potential emission sensitivities (PES), representing the sensitivity of the air mass to emissions from the surface at a given location, were averaged over either the entire column (all six altitude levels) or the first $200 \mathrm{~m}$ (first altitude level) and integrated back in time 10 days. PES plots shown in this work were further averaged over several days (up to the length of the entire campaign). Maps were generated using the Basemap toolkit for Python 3.6.

\section{Results and discussion}

\subsection{General transport pattern affecting the sampling site}

FLEXPART-ECMWF results indicate that the air arriving at Alert had spent at least the last 10 days within the Arctic circle (Fig. 2a and b), consistent with the established notion of a transport barrier into the Arctic, often referred to as the polar dome (Stohl, 2006; Klonecki et al., 2003). Furthermore, enhanced wet deposition in the Arctic boundary layer in summer tends to reduce the atmospheric lifetime of scavengeable species such as FA and AA, making long-range transport less likely (Croft et al., 2016). Indeed, aerosol concentrations reach very low levels in the summer Arctic atmosphere as a result of these scavenging processes (Barrie and Barrie, 1990; Croft et al., 2016; Li et al., 1993; Leaitch et al., 2013). Given these characteristics of transport from lower latitudes to Alert, we do not believe that sources such as biomass burning were important contributors to the mixing ratios observed during this campaign. Furthermore, aerosol mass loadings as measured by the SMPS never exceeded $0.46 \mu \mathrm{g} \mathrm{m}^{-3}$, and were only $0.13 \mu \mathrm{g} \mathrm{m}^{-3}$ on average during the campaign.

The complex topography and coastal situation of Alert result in the local meteorology being significantly influenced by mesoscale circulation processes. This influence is apparent in Fig. 2c, which shows a clear division between strong southwesterlies and weak northeasterlies. These wind regimes are characteristic of Alert (Persson and Stone, 2007) and represent processes occurring on the $10-200 \mathrm{~km}$ mesoscale. While the high wind speed southwesterlies provide a larger potential for transport than do the low wind speeds of the northeasterlies, from the perspective of potential sources of FA and AA, the landscape surrounding Alert is fairly homogeneous on that length scale. This is borne out by FLEXPART-ECMWF PES plots (Fig. S4) showing that the source regions during the two wind regimes similarly encompass sea ice, parts of Ellesmere Island, and some open water to the south.

The mixing ratios of FA and AA shown in Fig. 3 (5-min averages) display two striking features: high variability on two temporal scales (minutes and days) with occasional excursions to very high values (Figs. 3 and 4); and a clear dependence on wind direction. In Fig. 3, several time periods have been highlighted with orange bars. These are times of southwesterly flow, which was always associated with high wind speeds, usually displayed low relative humidities, and often coincided with an increase in temperature. During the rest of the campaign the site experienced much lower wind speeds and variable wind directions. These two distinct regimes are visible in the wind rose shown in Fig. 2c.

The observed dependence of the FA and AA mixing ratios on wind direction could potentially reflect regional het- 


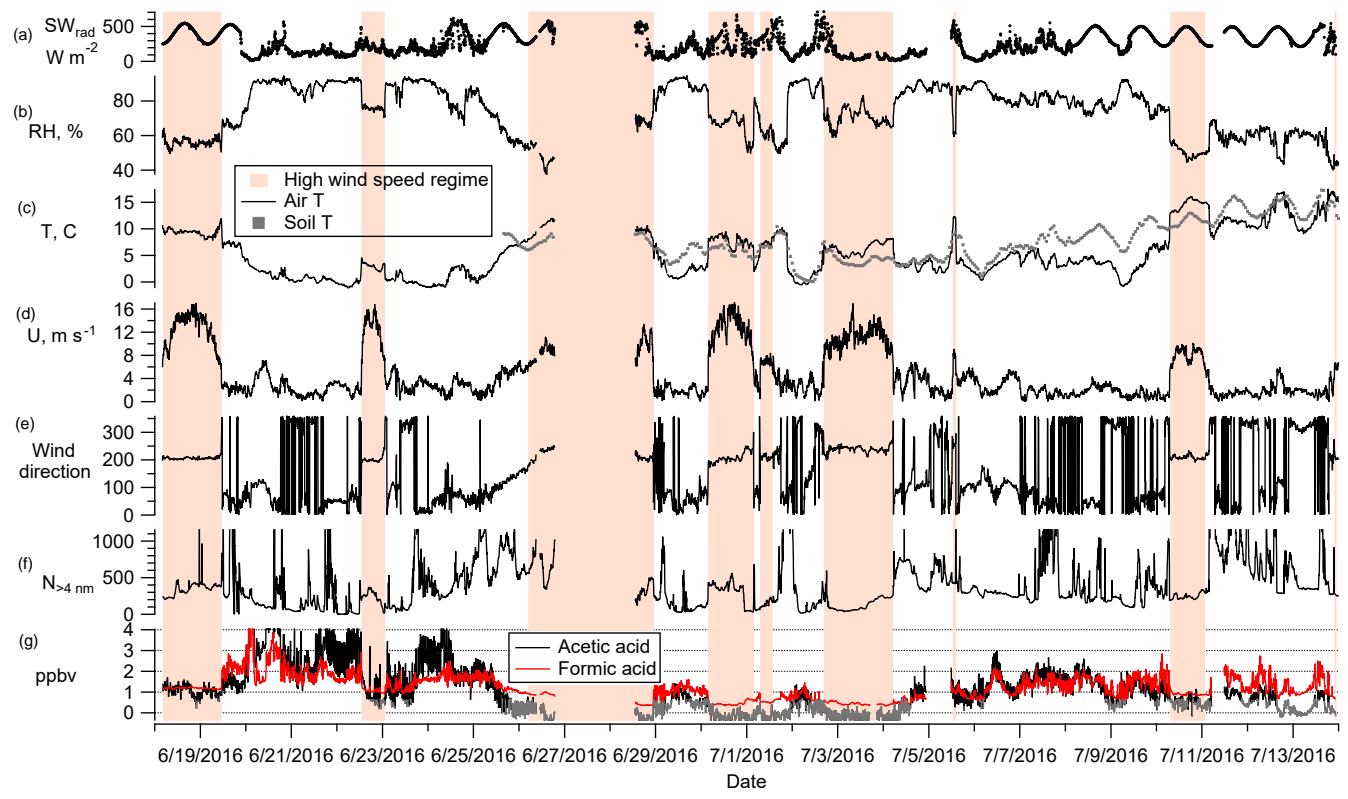

Figure 3. Time series of all data collected for the campaign ( 5 min averages). From top to bottom: total downwelling shortwave radiation, relative humidity, air temperature and soil temperature, wind speed, wind direction, aerosol particles, and FA (red) and AA (black, with values below the detection limit shown in gray.) The vertical axis is truncated at 4 ppbv for the organic acids and $1200 \mathrm{~cm}^{-3}$ for the aerosol particles. Orange bars highlight the high wind speed regime.

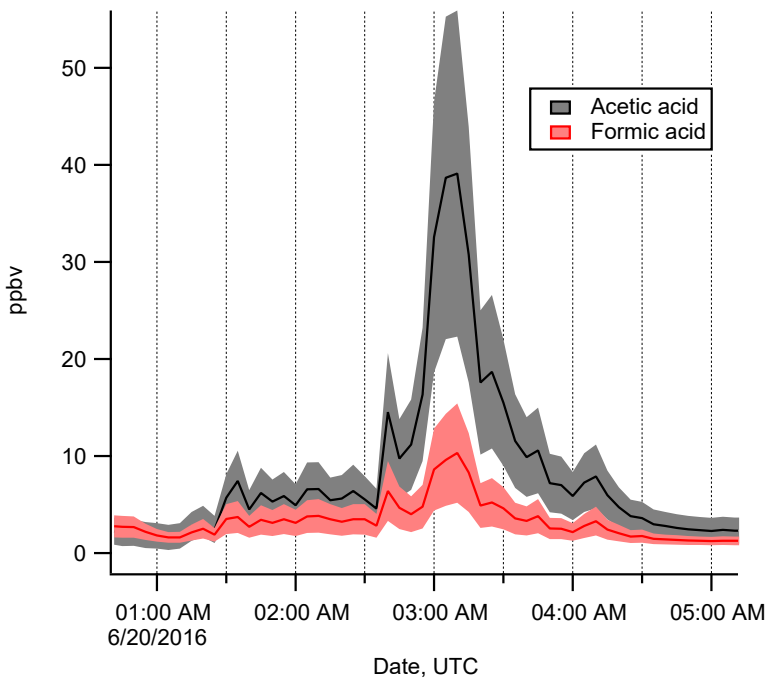

Figure 4. Expanded view of the time series on 20 June 2016, during which a very large excursion in FA and AA mixing ratios was observed. Note the factor of 10 difference in the $y$ axis scale. This large excursion to high values took place during a light precipitation event under stagnant $\left(\sim 1.5 \mathrm{~m} \mathrm{~s}^{-1}\right)$, cool $\left(\sim 4^{\circ} \mathrm{C}\right)$, and low-light (overcast) conditions. Shaded areas indicate calibration uncertainty (range between highest and lowest estimate, Sect. S1).

erogeneity in sources, sinks, or in source strength. However, given the consistency in source regions between the two wind regimes and the general regional Arctic nature of the sam- pled air masses, a focus on local processes is appropriate for this data set. While the specific time variations in FA and AA mixing ratios we observed are inextricably linked to the complex local topography and meteorology, the inferences drawn about possible sources are generalizable to similar High Arctic environments.

\subsection{Role of meteorology in determining FA and AA mixing ratios}

In Fig. 3, lower mixing ratios are seen to coincide with the high wind speed regime. Average mixing ratios of FA and AA for the whole campaign as well as averages over both regimes are summarized in Table 1 . The mean mixing ratios for the two regimes are statistically different from each other at the $95 \%$ confidence level. The average mixing ratios during the high wind speed regime $(0.76$ and 0.33 ppbv for FA and AA, respectively) were a factor of 2 and 4, respectively, lower than those during the low wind speed regime (1.48 and $1.46 \mathrm{ppbv}$ for FA and AA, respectively). However, the average mixing heights as determined from radiosonde measurements were about $450 \mathrm{~m}$ for the high wind speed regime and $200 \mathrm{~m}$ for the low wind speed regime (Sect. S2). Assuming that FA and AA (or their precursors) are directly emitted, and well mixed within the boundary layer, the factor of 2 difference in mixing heights can account for a factor of 2 difference in mean mixing ratios between these two regimes, suggesting that relative magnitude of sources and sinks may have been similar between regimes for FA. The additional 
factor of 2 difference in AA between the two wind regimes is likely spurious. There were fewer high wind events during the latter half of the campaign, when AA was also lower. The decrease in AA across the campaign may indicate a shift to sources with a higher FA to AA ratio. There are some indications that a higher FA to AA ratio is associated with biogenic sources of these acids (Khare et al., 1999; Talbot et al., 1988), but as no conclusive evidence exists we have not attempted to use this changing ratio to further our analysis.

The standard deviations of FA and AA for the entire campaign, the high wind speed regime, and the low wind speed regime are also shown in Table 1 . The relative stability of the mixing ratios during the high wind speed regime (as indicated by the smaller standard deviation values) likely reflects the stronger winds promoting mixing and leading to more constant mixing ratios. Thus the most striking behavior of the mixing ratios (i.e., the difference between the high and low wind speed regimes) is most likely simply due to mixing considerations and is not chemistry or source related. We suggest that the high variability at short timescales during the low wind speed regime is reflecting sources of FA and AA which are in close enough proximity to the measurement site that the variability has not been smoothed out by mixing processes. The variability also suggests that the sources are likely not only local but heterogeneous and/or sporadic, such that measured mixing ratios will be strongly affected by slight changes in wind direction or fluctuations in source strength.

It is worth noting that compared to midsummer mixing heights at mid-latitudes, which are typically $\sim 1 \mathrm{~km}$, the measured mixing heights for Alert are found to be very low. Determination of the boundary-layer mixing height at Arctic locations is made complex by the interactions of snowcovered surfaces, sea ice, and open water (Anderson and Neff, 2008). While the unstable conditions of well-mixed surface boundary layers do occur in summer, they are less common at Alert than statically stable conditions, where the potential temperature increases monotonically with height, so that mixing is suppressed. Typically the rate of increase in potential temperature is large enough that the physical temperature increases, leading to a surface-based temperature inversion (SBI). SBIs are generally found even when an unstable mixing layer exists at a lower altitude. SBIs in polar regions have been the subject of a number of studies (Bourne et al., 2010; Aliabadi et al., 2016), and are often taken as an indicator of boundary layer height (Bradley et al., 1993; Seidel et al., 2010). Although it is not obvious why the depth of an SBI should correspond to the depth of a mixed surface layer, as the strong gradient of potential temperature should strongly suppress mixing, rather than encourage it, ozone soundings at Alert and other Arctic sites typically show strong gradients of ozone and relative humidity at this height (Tarasick and Bottenheim, 2002). However, this may reflect previous boundary layer mixing and subsequent
Table 1. Mean mixing ratios (in ppbv) of FA and AA for the entire campaign, the high wind speed regime, and the low wind speed regime \pm one standard deviation.

\begin{tabular}{rrrr}
\hline & $\begin{array}{r}\text { Campaign } \\
\text { average }\end{array}$ & $\begin{array}{r}\text { High } \\
\text { wind speed } \\
\text { regime }\end{array}$ & $\begin{array}{r}\text { Low } \\
\text { wind speed } \\
\text { regime }\end{array}$ \\
\hline FA & $1.23 \pm 0.63$ & $0.76 \pm 0.32$ & $1.48 \pm 0.64$ \\
AA & $1.13 \pm 1.54$ & $0.33 \pm 0.57$ & $1.46 \pm 1.77$ \\
\hline
\end{tabular}

transport, possibly from the nearby ice zone, or differential transport of layers (Anderson and Neff, 2008).

Since the sources of formic and acetic acid are land-based and presumed local (unlike surface ozone depletion events), the relevant parameters are the convective mixing height, where it exists, and the vertical gradient of potential temperature, as a measure of the resistance to mixing (rather than the SBI height, which may represent non-local conditions). These were calculated from twice-daily radiosoundings at Alert (Fig. S5). In general, more stable conditions exist during the low wind speed regime. A convective mixing height is found for only $60 \%$ of all soundings, but where it exists, it averages $189 \mathrm{~m}$, compared to $440 \mathrm{~m}$ during the high wind speed regime. A similar difference is evident in the gradient of potential temperature: between the surface and $1 \mathrm{~km}$, the change in potential temperature is $7.5 \mathrm{~K}$ during the low wind speed regime, and $4.0 \mathrm{~K}$ during the high wind speed regime. In either case the difference is approximately a factor of 2. SBI heights are also greater during the high wind speed regime ( $803 \mathrm{~m}$ vs. $595 \mathrm{~m})$.

The low mixing heights are relevant when considering the high magnitudes of the mixing ratios reported here, as dilution is decreased with lower mixing heights. Similar emissions at mid-latitudes might result in a factor of 3 to 4 lower mixing ratios due to dilution into a deeper boundary layer. The high mixing ratios combined with a fairly stable atmosphere are also suggestive of strong vertical gradients of the acid concentrations such as would result from surface sources. Possible candidates for these surface sources are discussed in Sect. 3.4.

\subsection{Precipitation data}

The precipitation data collected during the campaign are summarized in Table 2. Also listed are the calculated depositional fluxes of formate and acetate based on these measurements (Sect. S3.2). The volume-weighted average concentrations over the entire campaign were $4.3 \mu \mathrm{M}$ for AA and $4.2 \mu \mathrm{M}$ for FA. Decades of measurements of formate and acetate in rainwater have found the values to range between 0.1 and $33 \mu \mathrm{M}$, with no clear dependence on the type of environment (i.e., urban, rural, remote) (Khare et al., 1999; Talbot et al., 1988, 1992; Kawamura et al., 1996, 2001). The values measured in this study fall within that range and are 


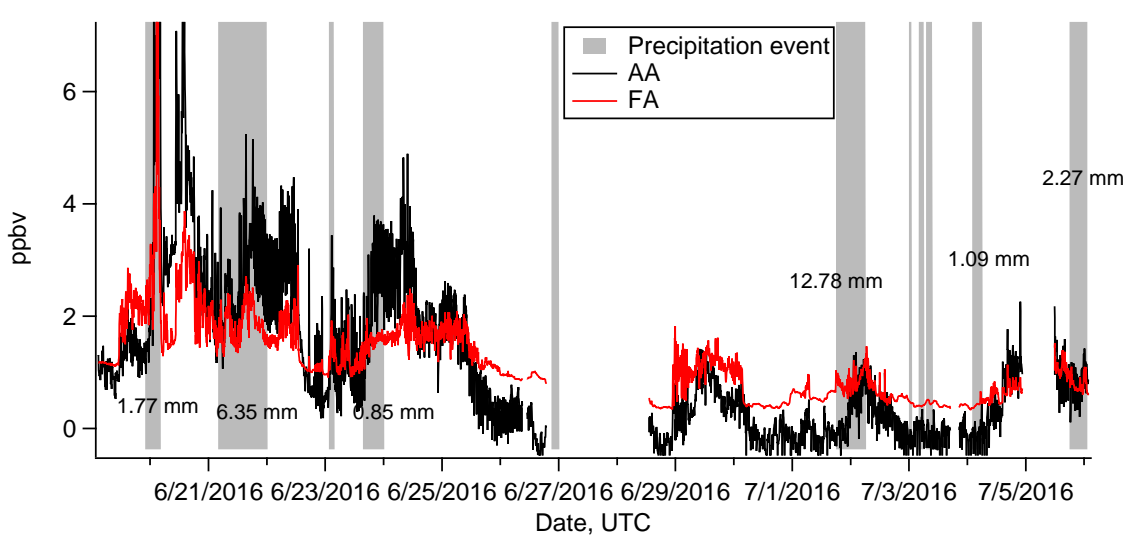

Figure 5. Time series FA (red) and AA (black). Gray bars indicate the duration of precipitation events as determined from all-sky camera images. Precipitation amounts (in $\mathrm{mm}$ ) are shown where data are available.

Table 2. Precipitation data for FA and AA.

\begin{tabular}{lrrrrrrr}
\hline Sampling date & 20 June & 22 June & 24 June & 27 June & 2 July & 4 July & 6 July \\
\hline Precipitation type & rain & snow & rain & rain & snow & rain and snow & rain and snow \\
Precipitation $(\mathrm{mm})$ & 1.77 & 6.35 & 0.85 & 1.38 & 12.78 & 1.09 & 2.27 \\
\hline FA concentration $(\mu \mathrm{M})$ & 3.2 & 2.3 & 4.7 & 5.6 & 1.9 & 40.0 & 5.9 \\
AA concentration $(\mu \mathrm{M})$ & 3.1 & 2.1 & 12.2 & 4.9 & 1.9 & 33.4 & 6.9 \\
FA deposition $\left(\mu \mathrm{mol} \mathrm{m}^{-2}\right)$ & 5.6 & 14.3 & 4.0 & 7.7 & 23.8 & 43.5 & 13.4 \\
AA deposition $\left(\mu \mathrm{mol} \mathrm{m}^{-2}\right)$ & 5.5 & 13.5 & 10.4 & 6.7 & 24.5 & 36.3 & 15.7 \\
\hline Estimated $\mathrm{pH}$ & 5.0 & 5.5 & 5.7 & 5.7 & 5.3 & 4.2 & 5.3 \\
\hline
\end{tabular}

consistent with studies in remote subpolar areas reporting annual volume-weighted mean concentration ranges from $\sim 1$ to $8 \mu \mathrm{mol} \mathrm{L}^{-1}$ (see Vet et al., 2014, and references therein).

The rate of scavenging of highly soluble gas-phase compounds by precipitation is expected to be on the order of 1$3 \% \mathrm{~min}^{-1}$ (Seinfeld and Pandis, 1998). The estimated durations of the precipitation events which occurred during the campaign are shown as gray bars in Fig. 5. The precipitation events lasted for at least an hour and usually longer, up to an entire day. FA and AA have very high effective Henry's law constants at the $\mathrm{pH}$ of the precipitation (estimated in Table 2 as $-\log \left[\sum\right.$ (anions) $-\sum$ (cations) $\left.]\right)$. We might thus expect significant depletion of the gas-phase mixing ratios of FA and AA through precipitation scavenging, particularly as the precipitation events were generally associated with low wind speeds, and thus presumably with little advection of FA and AA (Fig. 3). This expectation can be evaluated by comparing the deposition that would be associated with complete scavenging of the column to the measured deposition (Table 2). Using representative values for the mixing ratio ( 1 ppbv assuming that the mixing ratio measured at ground-level is representative of the entire column) and the boundary layer height ( $200 \mathrm{~m}$, see Sect. 3.2), we find that the estimated deposition is very similar to the measured deposition ( $\sim 6 \mu \mathrm{mol} \mathrm{m} \mathrm{m}^{-2}$, details in Sect. S3.2). While subject to a number of assumptions and uncertainties, these calculations nonetheless suggest that at least some scavenging of the column is likely, and should result in decreases of the measured mixing ratios at the ground. However, it is clear from Fig. 5 that this was not observed. Indeed, in many cases the mixing ratios of FA and AA actually increase during the precipitation events, indicating that the FA and AA mixing ratios are being maintained against a depletion process via wet deposition. This observation is suggestive of a surface source of FA and AA to the boundary layer, which may be enhanced during precipitation events. Large enhancements of FA and AA mixing ratios during (Warneke et al., 1999; Yuan et al., 2015; Greenberg et al., 2012) or immediately following (Sanhueza and Andreae, 1991; Talbot et al., 1988; Greenberg et al., 2012) precipitation events have been reported previously. Both biological (Sanhueza and Andreae, 1991) and chemical (Warneke et al., 1999; Greenberg et al., 2012) mechanisms have been proposed for enhanced release of FA and/or AA from soil surfaces as a result of precipitation. We will discuss these mechanisms further in Sect. 3.4.5. 

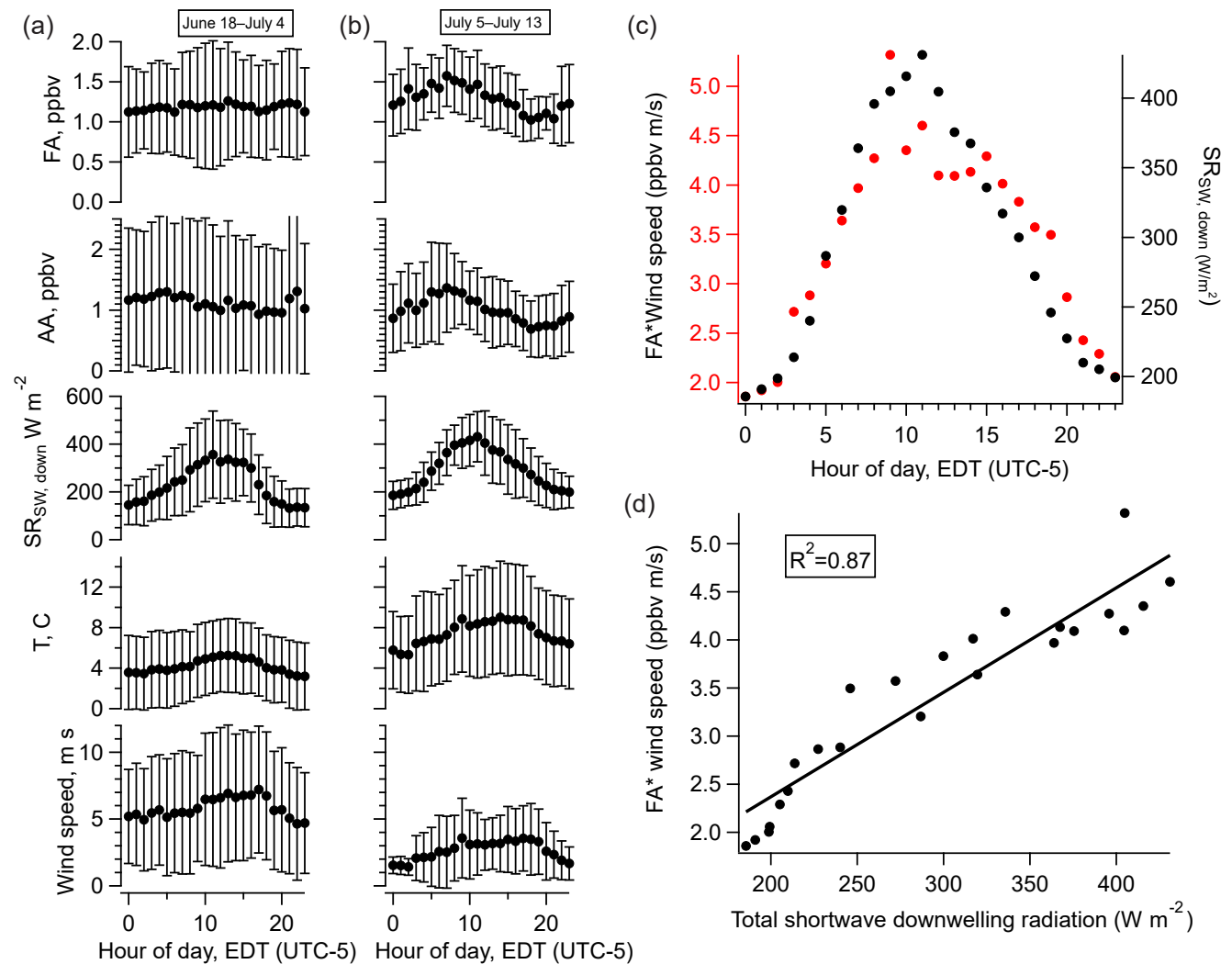

Figure 6. (a) Diurnal cycles of FA, AA, total downwelling shortwave radiation, temperature, and wind speed averaged over the entire campaign; (b) averaged over the period 5-13 July 2016; (c) the diurnal cycle of FA weighted by that of wind speed (red, left axis) and the diurnal cycle of total downwelling shortwave radiation (black, right axis); (d) the relationship between the quantities plotted in (c). Error bars in (a) and (b) represent one standard deviation.

\subsection{Possible sources of FA and AA}

Summer is short in the High Arctic, and during the course of this campaign the environment underwent a dramatic shift from late spring (snowpack remaining, little vegetation) to midsummer (very little snow remaining, comparatively extensive vegetation). Additionally, the fractional sky cover differed between the beginning and end of the campaign, with values of 0.69 and 0.36 , respectively, during the earlier (18 June to 4 July 2016) and later (5 July to 13 July 2016) portions of the campaign. As the environmental conditions changed, it is likely that the relevant sources of FA and AA also underwent changes. The lifetimes of FA and AA are also likely to have changed over time. In particular, their lifetimes were longer once the ground dried up post-snowmelt, reducing the impact of deposition. However, in the case of $\mathrm{AA}$, this increase in lifetime may have been at least partially counteracted by the effect of increased sunlight during the latter, brighter half of the campaign, which may have led to increases in photo-oxidation and a corresponding increase in the lifetime of AA. For these reasons, the analysis below frequently divides the campaign in two and discusses the earlier and later portions separately. Time itself is thus an important variable, meaning that it may not be desirable to compare, for example, a sunny day at the beginning of the measurement time period to a sunny day towards the end.

\subsubsection{Diurnal variability}

The amplitude of the diurnal cycles of FA and AA averaged over the entire campaign is very small. Restricting our analysis to the less overcast later period reveals a pronounced diurnal cycle in the acids, in contrast to the first half of the campaign (Fig. 6). However, the diurnal cycles of FA and AA peak a few hours before solar radiation or temperature. This can be accounted for by considering the effects of wind speed. Scaling the diurnal cycles of FA and AA by the diurnal cycle of wind speed produces a diurnal profile which matches that of solar radiation very well (Fig. 6). Linear regression allows us to quantify how well wind speed and solar radiation can explain the diurnal cycles of FA and AA. Table 3 summarizes the $R^{2}$ values for the relationships between the acids and solar radiation or wind speed alone or in combination (i.e., for a multiple linear regression of the form $y=m_{1} x_{1}+m_{2} x_{2}+b$ ). These values show that wind speed alone has essentially no explanatory power, solar radi- 
Table 3. $R^{2}$ values for the correlations of the diurnal cycles of FA and AA with solar radiation, wind speed, or both during the period 5-13 July 2016.

\begin{tabular}{cccc}
\hline & $\begin{array}{c}\text { Solar } \\
\text { radiation }\end{array}$ & $\begin{array}{c}\text { Wind } \\
\text { speed }\end{array}$ & $\begin{array}{c}\text { Solar radiation plus } \\
\text { wind speed }\end{array}$ \\
\hline FA & 0.29 & 0.01 & 0.80 \\
AA & 0.27 & 0.00 & 0.69 \\
\hline
\end{tabular}

ation alone can explain $\sim 30 \%$ of the diurnal variation in FA and $\mathrm{AA}$, and solar radiation and wind speed combined can explain $\sim 70-80 \%$ of the diurnal variation in these acids. The explanatory power of solar radiation suggests the presence of a photo-oxidative source during the latter half of the campaign. The modulation of the diurnal cycles of FA and AA by wind speed may indicate a surface source, because a source at the surface would result in an upward gradient of FA and AA. An increase in wind would act to reduce that vertical gradient by mixing the compounds upward, decreasing the mixing ratio measured near the surface. There are two possibilities as to the identity of the photo-oxidative source: heterogeneous oxidation at surfaces or gas-phase oxidation of reduced compounds, for example of biogenic volatile organic compounds (BVOCs). These possible sources will be further discussed below.

\subsubsection{Anthropogenic emissions}

Wind directions during the low wind speed regime were often from the northeast, such that the measurement site was downwind of the Canadian forces station Alert (CFS Alert) located $7 \mathrm{~km}$ to the northeast. These conditions make it important to determine if there is a local anthropogenic source contributing to the FA and AA mixing ratios. Although anthropogenic emissions are not generally thought to be important sources of FA and AA on a global scale, these acids and their precursors certainly have anthropogenic sources in some locales. Activities at CFS Alert that could potentially affect the measured mixing ratios of FA and AA include the diesel generator powering the station, cooking fumes, and vehicular emissions (although there are less than a dozen vehicles on station). FA and AA are emitted directly from these sources (Crisp et al., 2014; Bannan et al., 2014; Liggio et al., 2017) as well as formed photochemically from these emissions (Liggio et al., 2017; Yuan et al., 2015).

Unfortunately, no chemical tracers that would allow for conclusive evaluation of anthropogenic influence were measured during the campaign. However, each of the combustion sources mentioned above also emits aerosol particles, which were measured. We follow two lines of reasoning involving particle concentrations to conclude that combustion sources were not major contributors to the FA and AA measured during this campaign. First, if we consider aerosol number con- centrations as a tracer for combustion sources, the lack of correlation $\left(R^{2}<0.01\right)$ between the number of aerosol particles measured by the CPC (particles $>4 \mathrm{~nm}$ ) and FA and AA argues against a combustion source for the acids. Second, we can use the particle concentrations to evaluate the extent of the dilution a pollution plume originating at the station would have undergone before arriving at the GAW lab. The highest particle concentrations observed at the GAW lab during the campaign were about $10^{3}$ particles $\mathrm{cm}^{-3}$. Combustion sources emit many very small particles which quickly coagulate to yield accumulation mode particle densities on the order of $10^{6}$ particles $\mathrm{cm}^{-3}$ in near-source ambient air (Tang et al., 2016). We conclude that the aerosol particles have been diluted by at least 2 or 3 orders of magnitude before arriving at the GAW lab. The FA and AA mixing ratios observed during the low wind speed regime $(\sim 2 \mathrm{ppbv})$ are on the order of those observed in highly polluted urban areas (e.g., the Po Valley, LA; Atlanta Yuan et al., 2015; Millet et al., 2015) and close to sources (Bannan et al., 2014). Even accounting for the lower boundary layer at Alert, which might lead to a factor of 5 enhancement in mixing ratios for the same magnitude of emissions, the levels of FA and AA we observed are not consistent with combustion emissions that have been diluted by 3 orders of magnitude. It is also very unlikely that the aerosol particles could undergo 3 orders of magnitude of dilution while the acids remained undiluted. Hence the maximum amount of FA or AA that would arrive at the laboratory to be sampled would be on the order of 10 pptv (considering a 3 orders of magnitude dilution of $10 \mathrm{ppbv}$ and accounting for an enhancement in the mixing ratio due to the low mixing height), constituting a minor contribution even to the lower mixing ratios measured during this campaign $(\sim 200 \mathrm{pptv})$. We conclude that CFS Alert was not a major contributor to the FA and AA mixing ratios observed during the campaign.

\subsubsection{Heterogeneous chemistry}

Heterogeneous oxidation reactions produce both FA and AA (Vlasenko et al., 2008; Molina et al., 2004), although the mechanism by which this occurs is not yet understood. Of particular relevance to the present study are recent observations of mixing ratios of FA of similar magnitude to those reported here above open water in Nares Strait, only $\sim 300 \mathrm{~km}$ from Alert, which were attributed to heterogeneous chemistry at the sea surface microlayer (Mungall et al., 2017). Significant transport of air masses from the European Arctic and Baffin Bay to Alert does occur (Sharma et al., 2012), raising the possibility that a marine source contributed to the measured mixing ratios of FA and AA. However, there is little open ocean in the vicinity of Alert in June and July 2016 (Fig. S3), and, as will be discussed in the following sections, there were several likely sources of FA and AA much nearer to the point of measurement. Additionally, the environment surrounding the laboratory offered an abundance of 
other aqueous surfaces. During the snowmelt period, shallow ponds form over large areas of the tundra, and the lakes lose their ice coverage. These natural waters contain photochemically active dissolved organic matter (Laurion and Mladenov, 2013), and as such are good candidates for heterogeneous production of volatile organic compounds (VOCs; Brüggemann et al., 2017; Ciuraru et al., 2015; Fu et al., 2015). Indeed, the presence of surfactants in these water bodies is indicated by observations of foam at their margins (Fig. S6). Heterogeneous chemistry could also act to oxidize organic molecules present at soil surfaces.

Considering the diurnal variation in FA and AA (Sect. 3.4.1), which was also observed for FA in Nares Strait (Mungall et al., 2017), and the apparent ubiquity of the heterogeneous production of FA and AA, it seems likely that heterogeneous production from soil or water surfaces was a source of FA and AA throughout the campaign. Unfortunately, without further information, it is impossible to assess the extent of the contribution of heterogeneous oxidation processes to the observed FA and AA, although we believe that this source deserves further consideration in future work.

\subsubsection{Snowpack emissions}

The campaign took place during the snowmelt period. At the beginning of the measurement period, significant snowpack remained (Fig. 1b), but by the end of the measurement period, it had all melted (Fig. 1c). The first half of the campaign, when significant snowpack remained, was also a time of elevated FA and AA mixing ratios (20-26 June 2016, Fig. 3). Arctic snowpacks have been previously shown to give rise to significant mixing ratios of FA and AA (Dibb and Arsenault, 2002) as well as other oxygenated volatile organic compounds (OVOCs) (Grannas et al., 2007). The purported mechanism for this release is photochemistry. As the first half of the measurement period was quite dark due to heavy cloud cover (Fig. 3), particularly during times of elevated FA and AA, photochemistry seems unlikely to account for our observations.

Recent work quantifying formate and acetate in fresh snow at Alert found levels of 10 and $20 \mu \mathrm{g} \mathrm{kg}^{-1}$, respectively (Macdonald et al., 2017). Here we examine the feasibility of the partitioning of FA and AA from melting snow giving rise to the observed mixing ratios. We can use the effective Henry's law constants $\left(K_{\mathrm{H}}^{*}\right)$ of FA and AA to calculate their expected partitioning behavior from the melted snow from Eq. (3)
$K_{\mathrm{H}}^{*}=K_{\mathrm{H}}\left(1+\frac{K a}{\left[H^{+}\right]}\right)$,

$K_{\mathrm{H}}^{*}=\frac{C_{1}}{C_{\mathrm{g}}}$,

$C_{\mathrm{g}}=\frac{C_{1}}{K_{\mathrm{H}}^{*}}$,

where $C_{\mathrm{g}}$ is the gas-phase partial pressure in bar, $C_{1}$ is the aqueous phase concentration in molarity $\mathrm{M}, K_{\mathrm{H}}$ is the Henry's law constant for a given temperature (Johnson et al., 1996), and $\mathrm{Ka}$ is the acid dissociation constant $\left(1.810^{-4}\right.$ for FA and $1.74 \times 10^{-5}$ for AA). Assuming that the concentrations for formate (acetate) and $\mathrm{pH}$ measured in freshly fallen snow samples apply to the aged, melting, late-spring snowpack, meltwater would be in equilibrium with approximately 0.1 pptv (3 pptv) in the gas phase, or about $0.001 \%(0.01 \%)$ of the peak measured mixing ratios as are summarized in Table 4 .

These values are far too small to account for our observations. However, the formate and acetate concentrations used in these calculations are for fresh snow. The aged snowpack present during our measurements might be expected to contain much higher solute concentrations. Additionally, bulk concentrations measured in melted snow likely do not accurately represent the concentrations present at the surface of the snow in the environment. Concentration of solutes might occur in a liquid layer at the edges of snow crystals, or as a result of freeze-thaw cycles; additionally, the first flush of meltwater or rain percolating through the snowpack would contain very high concentrations of solutes (Kuhn, 2001; Meyer et al., 2009). The snowpack surrounding the laboratory also experienced frequent precipitation during the time period of elevated mixing ratios (Fig. 5), which would contribute to snowmelt. If these processes led to a decrease in $\mathrm{pH}$ below the pKa of FA or AA, the acids would be considerably more likely to partition to the gas phase. However, a 3 orders of magnitude increase in concentration as a result of freeze-thaw cycles or solute exclusion would be required for equilibrium partitioning to explain our observations. Finally, we note that from a mass balance perspective, the snowpack contained sufficient formate and acetate to give rise to the observed high mixing ratios in the extreme case of all of the formate and acetate being released to the gas phase. For example, the complete evaporation of a $30 \mathrm{~cm}$-deep snowpack containing the formate and acetate values given in Table 4 would yield FA and AA mixing ratios of 8 and 12 ppbv, respectively, if mixed up to a $200 \mathrm{~m}$ mixing height.

\subsubsection{Soil emissions}

Direct emissions of FA and AA from soil are highly unconstrained. While FA and AA are known to be produced by soil bacteria (Paulot et al., 2011), a single direct observation of 
Table 4. Estimated equilibrium mixing ratios for literature values of formate and acetate in snow and soil. Measured values for comparison are higher for the snow case as mixing ratios were higher earlier in the campaign. pH values for snow are for melted fresh snow at Alert (Macdonald et al., 2017). pH values for soil were measured from soil cores in the vicinity of Alert (Sect. 2.5).

\begin{tabular}{lrrrrrrr}
\hline & $C_{1}\left(\mathrm{mg} \mathrm{L}^{-1}\right)$ & $\mathrm{pH}$ & $\mathrm{T}$ & $K_{\mathrm{H}}^{*}\left(\mathrm{M} \mathrm{hPa}^{-1}\right)$ & Estimated $C_{\mathrm{g}}(\mathrm{ppbv})$ & Measured $C_{\mathrm{g}}(\mathrm{ppbv})$ & Percent explained \\
\hline FA (snow) & 0.01 & 5.37 & 0 & $2.4 \times 10^{6}$ & 0.0001 & 3 & 0.005 \\
AA (snow) & 0.02 & 5.37 & 0 & $1.4 \times 10^{5}$ & 0.003 & 4 & 0.1 \\
\hline FA (soil) & 2 & 6.5 & 15 & $1.0 \times 10^{7}$ & 0.004 & 1.5 & 0.3 \\
AA (soil) & 1 & 6.5 & 15 & $4.6 \times 10^{5}$ & 0.05 & 1.5 & 3.1 \\
\hline
\end{tabular}

their emission from a soil surface exists (Sanhueza and Andreae, 1991). In 1988, a study in the southeast United States saw that atmospheric FA mixing ratios began to rise in spring before deciduous trees got their leaves and suggested that a soil source might be responsible for these observations, and in 1992 upward gradients of FA and AA from a boreal forest soil were interpreted as indicating a soil source (Enders et al., 1992). More recently, a flux measurement study of FA in the boreal forest concluded that a large direct soil or plant source was needed to explain those measurements (Schobesberger et al., 2016), and a study of the Fenno-Scandinavian Arctic wetlands suggested that the acidic, microbially active wetland soils might be a large source of FA (Jones et al., 2017). Given the large expanse of sparsely vegetated ground with a large percentage of bare soil surrounding our measurement site (e.g., Fig. 1d), we will consider the ability of soil emissions to contribute to the high measured mixing ratios of FA and AA.

First, we will consider the equilibrium partitioning of FA and AA between soil pore water and the atmosphere. The water-air partitioning of FA and AA can be estimated from Eq. (3) using measured soil temperature and $\mathrm{pH}$, effective Henry's law constants, and estimated soil formate and acetate concentrations (formate and acetate were chosen as $2 \mathrm{mg} \mathrm{L}^{-1}$, probably an upper limit for this region; Nielsen et al., 2017; Ström et al., 2012). Further uncertainty is introduced by using literature values for soil formate and acetate concentrations because it requires making the assumption that all the formate and acetate extracted from the soils in those studies resided in the soil pore water, which is unlikely to be the case. The results of this estimate are shown in Table 4. The soil reservoirs of formate and acetate would need to be 1 or 2 orders of magnitude larger than they have been measured to be in similar environments in order to contribute more than a few percent to FA and AA levels. A very acidic soil would also promote the emission of FA and AA, but the soil samples were taken from three different microenvironments (albeit all within $\sim 5 \mathrm{~km}$ of the station), and all samples had near-neutral $\mathrm{pH}$. Additionally, other work examining Arctic soils has generally found near-neutral $\mathrm{pH}$ (Brummell et al., 2012; Nielsen et al., 2017). While a combination of lower $\mathrm{pH}$ and higher soil reservoirs of formate and acetate could perhaps lead to somewhat larger emissions than those estimated here, we conclude that equilibrium soil-air partitioning is unlikely to account for the high mixing ratios of FA and AA observed in this study.

During the time of highest FA and AA mixing ratios towards the beginning of the campaign (i.e., 20-26 June 2016, Fig. 3), an excursion of FA and AA mixing ratios to extremely large values (11 and 40 ppbv respectively, Fig. 4) was observed. As this excursion occurred during the time of snowmelt (Fig. 1b and c), we propose that it may have formed part of a spring emissions pulse such as has been observed for nitrous oxide (Wagner-Riddle et al., 2008). An emissions pulse associated with a spring thaw might result from increased microbial activity during soil thawing or from partitioning to the atmosphere of a pool that has built up at depth and can be released once the snow has melted. Additionally, FA and AA emissions or mixing ratios have been observed previously to be enhanced during or after precipitation events, sometimes to quite large values similar to what we observed (Sanhueza and Andreae, 1991; Warneke et al., 1999; Yuan et al., 2015). One proposed explanation is that microbial production could be activated by the precipitation (Sanhueza and Andreae, 1991; Paulot et al., 2011). Pulses of FA or AA within the soil due to such a process would be transient, and might thus be quite different from the soil concentrations measured in the studies cited here. A chemical explanation for emission pulses has also been proposed. The suggestion is that adsorbed polar molecules could be flushed out during an influx of water (such as during a precipitation event) as the more polar water molecules are preferentially taken up onto the adsorption sites (Warneke et al., 1999; Goss et al., 2004). Additionally, "pulsing" behavior could arise from momentary $\mathrm{pH}$ changes in the soil during precipitation, allowing for the emission of FA and AA before the soil is buffered back to a more neutral $\mathrm{pH}$. We suggest that one or more of these pulsing mechanisms might provide an explanation for the unexpected increases of FA and AA during precipitation events, and potentially also for the very high mixing ratios observed on 20 June 2016 (Fig. 4). We wish to emphasize that further studies of direct emissions of FA and AA from soils, including the effects of precipitation, would be highly beneficial. 


\subsubsection{Plant emissions}

To our knowledge, no information on the direct emissions of FA and AA from Arctic flora exists in the literature. OVOCs, such as FA and AA, are produced as by-products of plant metabolism (Niinemets et al., 2014), and can either be emitted to the atmosphere or consumed by further metabolic processes. The direct emission of FA and AA from plants has been documented (Kesselmeier et al., 1998; Kuhn et al., 2002; Guenther et al., 2000), but is not generally considered to be an important source of these compounds to the atmosphere globally (although emission estimates vary widely; Paulot et al., 2011). A study of FA and AA in the central Amazon found bidirectional exchange of FA and AA between the forest canopy and the atmosphere (Jardine et al., 2011), with net upwards flux occurring in the absence of other sources, but net deposition when the atmosphere was impacted by advection of biomass burning plumes containing FA and AA. Hence whether the tundra was acting as a source or a sink of FA and AA during our measurement campaign likely depends on what other sources were contributing to the ambient levels of those acids.

That the current understanding of the secondary photochemical production of FA and AA is not sufficient to explain observations has been thoroughly established (Paulot et al., 2011; Yuan et al., 2015; Millet et al., 2015; Liggio et al., 2017). Despite the understanding of these processes being incomplete, it is clear that the photo-oxidation of BVOCs such as isoprene and monoterpenes is a very large source of FA and AA (Paulot et al., 2011, and references therein). The MEGAN v2.1 model (Guenther et al., 2012), which is widely used to estimate BVOC emissions globally, predicts very low BVOC emissions in the subarctic and no emissions at all in large parts of the Arctic, which the model classifies as bare soil. There are two problems with this. First, the High Arctic is not only bare soil, with even polar desert areas reaching 30\% vegetation coverage (Liu and Treitz, 2016), and ecosystem-scale BVOC emissions comparable to those in the subarctic have been measured from High Arctic vegetation (Schollert et al., 2013; Rinnan et al., 2014; Vedel-Petersen et al., 2015; Lindwall et al., 2016). Second, soil emissions of reactive alkanes have been inferred from ecosystem emission measurements (Schollert et al., 2013), raising the possibility that emissions of BVOCs from bare soil should also be considered in models. Because BVOC emissions are often temperature-dependent (Guenther et al., 2012), it is also worth noting that soil temperatures at $10 \mathrm{~cm}$ depth at times exceeded air temperatures (Fig. 3). The temperature a few centimeters above the ground in the summer Arctic can reach up to $10^{\circ} \mathrm{C}$ higher than routinely measured air temperatures (Schollert et al., 2013), perhaps explaining why emission measurements in the Arctic seem to be higher than those estimated from temperature-dependent parameterizations.

The emission of many plant volatiles is controlled to some extent by light and temperature (Guenther, 2013), and thus the mixing ratios of BVOCs commonly display distinct diurnal profiles. Hence the diurnal variability in FA and AA might point to a primary or secondary plant source for these acids, although the suggestion of an upward gradient in FA and AA (Sect. 3.4.1) makes it less likely that a secondary source is responsible for these observations. An upward gradient might be less likely to develop from a secondary source, as FA and AA production from precursors takes several hours at least (Liggio et al., 2017), allowing time for the precursor BVOCs to be mixed upward into the boundary layer. As we did not measure BVOC mixing ratios during this campaign, we cannot estimate the contribution of their oxidation to the FA and AA we measured. However, given that Arctic plants are known to emit BVOCs, it would be surprising if photo-oxidation of BVOCs did not contribute to some extent to FA and AA mixing ratios in the summer boundary layer. Measurements of precursors in conjunction with FA and AA would be useful to further explore this question.

\section{Conclusions}

We measured gas-phase mixing ratios of formic and acetic acids (FA and AA) as well as formate and acetate concentrations in precipitation over a 3-week period during summer 2016 at Alert, Nunavut. We observed high, and highly variable, mixing ratios of FA and AA, which we interpret as arising from regional sources within the Arctic. In particular, the surprisingly large magnitude of the mixing ratios is suggestive of not only a shallow boundary layer but also of strong vertical gradients resulting from a surface source. The first half of the campaign was relatively cold, wet, and overcast, and yet high mixing ratios of FA and AA were observed, with increases during and immediately following precipitation events. These observations indicate that high levels of FA and AA exist in a moist environment where the $\mathrm{pH}$ of soil and precipitation are larger than the $\mathrm{pKa}$ of these acids; that is, an environment in which physical equilibrium partitioning should not favor re-volatilization of FA and AA. Pulses of FA and AA from wet soil have been observed previously (Warneke et al., 1999; Sanhueza and Andreae, 1991), suggesting that similar biological or chemical mechanisms are at play in the Arctic environment. The second half of the campaign was relatively warm and sunny, and the FA and AA mixing ratios displayed diurnal cycles, suggesting the influence of photo-oxidation, whether of plant-emitted BVOCs or heterogeneous oxidation of surfaces. The relative importance of these various emission mechanisms likely changed over the study period in concert with the dramatic changes in the environmental conditions characteristic of the short Arctic summer.

Overall, this study supports the growing understanding that FA is ubiquitously produced and displays high mixing ratios in most environments where it is measured, and suggests the same for AA. Furthermore, the observation of high 
mixing ratios under very different environmental conditions - cold, wet, and overcast versus warm and sunny - highlight that FA and AA emission processes appear to be varied and complex. Furthermore, the most important processes appeared to be changing over the course of the campaign. These processes and their magnitudes are not adequately represented in chemical transport models, as evidenced by large underestimates of FA and AA mixing ratios in the region (Paulot et al., 2011). To work towards ameliorating the models, the next step should be to repeat these observations over a longer time period, both before the melt period and after, to better allow for elucidation of the changing sources. For measurements performed at Alert, efforts to diagnose the relative impacts of different meteorological processes (i.e., turbulent mixing versus advection) on the observed mixing ratios would be valuable. The measurement of vertical fluxes is also highly desirable, particularly with respect to inclusion in models. In conclusion, while it is clear that models are not capturing the processes affecting FA and AA in the Arctic, more information is required before those deficiencies can be addressed.

Data availability. NETCARE (Network on Climate and Aerosols: Addressing Key Uncertainties in Remote Canadian Environments, see http://www.netcare-project.ca, last access: 13 July 2018), which organized the field campaigns described in this work, is moving towards a publicly available, online data archive. In the meantime, data can be accessed by contacting the principal investigator of the network: Jonathan Abbatt, University of Toronto (jabbatt@chem.utoronto.ca).

Supplement. The supplement related to this article is available online at: https://doi.org/10.5194/acp-18-10237-2018-supplement.

Author contributions. JL, JPDA, and JM designed the experiment. ELM and JJBW collected the gas-phase data. GW collected the precipitation and soil data. SS facilitated the measurements. ELM performed the calibrations and analyzed the data. DK ran the FLEXPART-ECMWF model. EG provided meteorological expertise. DT analyzed the radiosonde data. CJC collected and analyzed the pyranometer data. ELM wrote the manuscript with contributions from all co-authors.

Competing interests. The authors declare that they have no conflict of interest.

Special issue statement. This article is part of the special issue "NETCARE (Network on Aerosols and Climate: Addressing Key Uncertainties in Remote Canadian Environments) (ACP/AMT/BG inter-journal SI)". It is not associated with a conference.
Acknowledgements. The authors would like to acknowledge the financial support of NSERC for the NETCARE project funded under the Climate Change and Atmospheric Research program. We gratefully acknowledge Richard Leaitch for facilitating the Alert campaign, as well as the GAW lab operator Kevin Rawlings and the co-op student Dana Stephenson. We are also grateful to everyone at CFS Alert, both military and Nasittuq, for their hospitality and help.

Edited by: Lynn M. Russell

Reviewed by: three anonymous referees

\section{References}

Aliabadi, A., Staebler, R., de Grandpré, J., Zadra, A., and Vaillancourt, P.: Comparison of estimated atmospheric boundary layer mixing height in the Arctic and Southern Great Plains under statically stable conditions: Experimental and numerical aspects, Atmos.-Ocean, 54, 60-74, https://doi.org/10.1080/07055900.2015.1119100, 2016.

Anderson, P. S. and Neff, W. D.: Boundary layer physics over snow and ice, Atmos. Chem. Phys., 8, 3563-3582, https://doi.org/10.5194/acp-8-3563-2008, 2008.

Baboukas, E. D., Kanakidou, M., and Mihalopoulos, N.: Carboxylic acids in gas and particulate phase above the Atlantic Ocean, J. Geophys. Res.-Atmos., 105, 14459-14471, https://doi.org/10.1029/1999JD900977, 2000.

Bannan, T. J., Bacak, A., Muller, J. B. A., Booth, A. M., Jones, B., Le Breton, M., Leather, K. E., Ghalaieny, M., Xiao, P., Shallcross, D. E., and Percival, C. J.: Importance of direct anthropogenic emissions of formic acid measured by a chemical ionisation mass spectrometer (CIMS) during the Winter ClearfLo Campaign in London, January 2012, Atmos. Environ., 83, 301310, https://doi.org/10.1016/j.atmosenv.2013.10.029, 2014.

Barrie, L. A. and Barrie, M. J.: Chemical components of lower tropospheric aerosols in the high Arctic: Six years of observations, J. Atmos. Chem, 11, 211-226, 1990.

Bourne, S., Bhatt, U., Zhang, J., and Thoman, R.: Surface-based temperature inversions in Alaska from a climate perspective, Atmos. Res., 95, 353-366, https://doi.org/10.1016/j.atmosres.2009.09.013, 2010.

Bradley, R. S., Keimig, F. T., and Diaz, H. F.: Recent changes in the North American Arctic boundary layer in winter, J. Geophys. Res.-Atmos., 98, 8851-8858, https://doi.org/10.1029/93JD00311, 1993.

Brüggemann, M., Hayeck, N., Bonnineau, C., Pesce, S., Alpert, P. A., Perrier, S., Zuth, C., Hoffmann, T., Chen, J. M., and George, C.: Interfacial photochemistry of biogenic surfactants: a major source of abiotic volatile organic compounds, Faraday Discuss., 200, 59-74, https://doi.org/10.1039/C7FD00022G, 2017.

Brummell, M. E., Farrell, R. E., and Siciliano, S. D.: Greenhouse gas soil production and surface fluxes at a high arctic polar oasis, Soil Biol. Biochem., 52, 1-12, https://doi.org/10.1016/j.soilbio.2012.03.019, 2012.

Chebbi, A. and Carlier, P.: Carboxylic acids in the troposphere, occurrence, sources, and sinks: A review, Atmos. Environ., 30, 4233-4249, https://doi.org/10.1016/1352-2310(96)00102-1, 1996. 
Ciuraru, R., Fine, L., van Pinxteren, M., D’Anna, B., Herrmann, H., and George, C.: Photosensitized production of functionalized and unsaturated organic compounds at the air-sea interface, Sci. Rep., 5, 12741, https://doi.org/10.1038/srep12741, 2015.

Crisp, T. A., Brady, J. M., Cappa, C. D., Collier, S., Forestieri, S. D., Kleeman, M. J., Kuwayama, T., Lerner, B. M., Williams, E. J., Zhang, Q., and Bertram, T. H.: On the primary emission of formic acid from light duty gasoline vehicles and ocean-going vessels, Atmos. Environ., 98, 426-433, https://doi.org/10.1016/j.atmosenv.2014.08.070, 2014.

Croft, B., Martin, R. V., Leaitch, W. R., Tunved, P., Breider, T. J., D'Andrea, S. D., and Pierce, J. R.: Processes controlling the annual cycle of Arctic aerosol number and size distributions, Atmos. Chem. Phys., 16, 3665-3682, https://doi.org/10.5194/acp16-3665-2016, 2016.

Dibb, J. E. and Arsenault, M.: Shouldn't snowpacks be sources of monocarboxylic acids?, Atmos. Environ., 36, 2513-2522, https://doi.org/10.1016/S1352-2310(02)00131-0, 2002.

Enders, G., Dlugi, R., Steinbrecher, R., Clement, B., Daiber, R., Eijk, J. v., Gäb, S., Haziza, M., Helas, G., Herrmann, U., Kessel, M., Kesselmeier, J., Kotzias, D., Kourtidis, K., Kurth, H. H., McMillen, R. T., Roider, G., Schürmann, W., Teichmann, U., and Torres, L.: Biosphere/Atmosphere interactions: Integrated research in a European coniferous forest ecosystem, Atmos. Environ., 26, 171-189, https://doi.org/10.1016/0960-1686(92)90269Q, 1992.

Ervens, B., Turpin, B. J., and Weber, R. J.: Secondary organic aerosol formation in cloud droplets and aqueous particles (aqSOA): a review of laboratory, field and model studies, Atmos. Chem. Phys., 11, 11069-11102, https://doi.org/10.5194/acp-1111069-2011, 2011.

Fu, H., Ciuraru, R., Dupart, Y., Passananti, M., Tinel, L., Rossignol, S., Perrier, S., Donaldson, D. J., Chen, J., and George, C.: Photosensitized Production of Atmospherically Reactive Organic Compounds at the Air/Aqueous Interface, J. Am. Chem. Soc., 137, 8348-8351, https://doi.org/10.1021/jacs.5b04051, 2015.

Glasius, M., Boel, C., Bruun, N., Easa, L. M., Hornung, P., Klausen, H. S., Klitgaard, K. C., Lindeskov, C., Møller, C. K., Nissen, H., Petersen, A. P. F., Kleefeld, S., Boaretto, E., Hansen, T. S., Heinemeier, J., and Lohse, C.: Relative contribution of biogenic and anthropogenic sources to formic and acetic acids in the atmospheric boundary layer, J. Geophys. Res.-Atmos., 106, 74157426, https://doi.org/10.1029/2000JD900676, 2001.

Goss, K.-U., Buschmann, J., and Schwarzenbach, R. P.: Adsorption of organic vapors to air-Dry soils: Model Predictions and Experimental Validation, Environ. Sci. Technol., 38, 3667-3673, https://doi.org/10.1021/es035388n, 2004.

Grannas, A. M., Jones, A. E., Dibb, J., Ammann, M., Anastasio, C., Beine, H. J., Bergin, M., Bottenheim, J., Boxe, C. S., Carver, G., Chen, G., Crawford, J. H., Dominé, F., Frey, M. M., Guzmán, M. I., Heard, D. E., Helmig, D., Hoffmann, M. R., Honrath, R. E., Huey, L. G., Hutterli, M., Jacobi, H. W., Klán, P., Lefer, B., McConnell, J., Plane, J., Sander, R., Savarino, J., Shepson, P. B., Simpson, W. R., Sodeau, J. R., von Glasow, R., Weller, R., Wolff, E. W., and Zhu, T.: An overview of snow photochemistry: evidence, mechanisms and impacts, Atmos. Chem. Phys., 7, 43294373, https://doi.org/10.5194/acp-7-4329-2007, 2007.

Greenberg, J. P., Asensio, D., Turnipseed, A., Guenther, A. B., Karl, T., and Gochis, D.: Contribution of leaf and needle litter to whole ecosystem BVOC fluxes, Atmos. Environ., 59, 302-311, https://doi.org/10.1016/j.atmosenv.2012.04.038, 2012.

Guenther, A.: Biological and chemical diversity of biogenic volatile organic emissions into the atmosphere, Atmos. Sci., 2013, 1-27, https://doi.org/10.1155/2013/786290, 2013.

Guenther, A., Geron, C., Pierce, T., Lamb, B., Harley, P., and Fall, R.: Natural emissions of non-methane volatile organic compounds, carbon monoxide, and oxides of nitrogen from North America, Atmos. Environ., 34, 2205-2230, https://doi.org/10.1016/S1352-2310(99)00465-3, 2000.

Guenther, A. B., Jiang, X., Heald, C. L., Sakulyanontvittaya, T., Duhl, T., Emmons, L. K., and Wang, X.: The Model of Emissions of Gases and Aerosols from Nature version 2.1 (MEGAN2.1): an extended and updated framework for modeling biogenic emissions, Geosci. Model Dev., 5, 1471-1492, https://doi.org/10.5194/gmd-5-1471-2012, 2012.

Ito, A. and Penner, J. E.: Global estimates of biomass burning emissions based on satellite imagery for the year 2000, J. Geophys. Res.-Atmos., 109, D14S05, https://doi.org/10.1029/2003JD004423, 2004.

Jardine, K., Yañez Serrano, A., Arneth, A., Abrell, L., Jardine, A., Artaxo, P., Alves, E., Kesselmeier, J., Taylor, T., Saleska, S., and Huxman, T.: Ecosystem-scale compensation points of formic and acetic acid in the central Amazon, Biogeosciences, 8, 37093720, https://doi.org/10.5194/bg-8-3709-2011, 2011.

Johnson, B. J., Betterton, E. A., and Craig, D.: Henry's law coefficients of formic and acetic acids, J. Atmos. Chem, 24, 113-119, https://doi.org/10.1007/BF00162406, 1996.

Jones, B. T., Muller, J. B. A., O’Shea, S. J., Bacak, A., Le Breton, M., Bannan, T. J., Leather, K. E., Booth, A. M., Illingworth, S., Bower, K., Gallagher, M. W., Allen, G., Shallcross, D. E., Bauguitte, S. J. B., Pyle, J. A., and Percival, C. J.: Airborne measurements of $\mathrm{HC}(\mathrm{O}) \mathrm{OH}$ in the European Arctic: A winter - summer comparison, Atmos. Environ., 99, 556-567, https://doi.org/10.1016/j.atmosenv.2014.10.030, 2014.

Jones, B. T., Muller, J., O’Shea, S., Bacak, A., Allen, G., Gallagher, M., Bower, K., Le Breton, M., Bannan, T. J., Bauguitte, S., Pyle, J., Lowry, D., Fisher, R., France, J., Nisbet, E., Shallcross, D., and Percival, C.: Are the Fenno-Scandinavian Arctic Wetlands a Significant Regional Source of Formic Acid?, Atmosphere, 8, 112, https://doi.org/10.3390/atmos8070112, 2017.

Kawamura, K., Ng, L. L., and Kaplan, I. R.: Determination of organic acids (C1-C10) in the atmosphere, motor exhausts, and engine oils, Environ. Sci. Technol., 19, 1082-1086, https://doi.org/10.1021/es00141a010, 1985.

Kawamura, K., Steinberg, S., and Kaplan, I. R.: Concentrations of monocarboxylic and dicarboxylic acids and aldehydes in southern California wet precipitations: Comparison of urban and nonurban samples and compositional changes during scavenging, Atmos. Environ., 30, 1035-1052, https://doi.org/10.1016/1352-2310(95)00404-1, 1996.

Kawamura, K., Steinberg, S., Ng, L., and Kaplan, I. R.: Wet deposition of low molecular weight mono- and di-carboxylic acids, aldehydes and inorganic species in Los Angeles, Atmos. Environ., 35, 3917-3926, https://doi.org/10.1016/S13522310(01)00207-2, 2001.

Kesselmeier, J., Bode, K., Gerlach, C., and Jork, E. M.: Exchange of atmospheric formic and acetic acids with trees and crop plants 
under controlled chamber and purified air conditions, Atmos. Environ., 32, 1765-1775, 1998.

Khare, P., Kumar, N., Kumari, K. M., and Srivastava, S. S.: Atmospheric formic and acetic acids: An overview, Rev. Geophys., 37, 227-248, https://doi.org/10.1029/1998RG900005, 1999.

Klemm, O., Talbot, R. W., Fitzgerald, D. R., Klemm, K. I., and Lefer, B. L.: Low to middle tropospheric profiles and biosphere/troposphere fluxes of acidic gases in the summertime Canadian taiga, J. Geophys. Res.-Atmos., 99, 1687-1698, https://doi.org/10.1029/93JD01754, 1994.

Klonecki, A., Hess, P., Emmons, L., Smith, L., Orlando, J., and Blake, D.: Seasonal changes in the transport of pollutants into the Arctic troposphere-model study, J. Geophys. Res.-Atmos., 108, 8367, https://doi.org/10.1029/2002JD002199, 2003.

Kuhn, M.: The nutrient cycle through snow and ice, a review, Aquat. Sci., 63, 150-167, https://doi.org/10.1007/PL00001348, 2001.

Kuhn, U., Rottenberger, S., Biesenthal, T., Ammann, C., Wolf, A., Schebeske, G., Oliva, S. T., Tavares, T. M., and Kesselmeier, J.: Exchange of short-chain monocarboxylic acids by vegetation at a remote tropical forest site in Amazonia, J. Geophys. Res.-Atmos., 107, 8069, https://doi.org/10.1029/2000JD000303, 2002.

Laurion, I. and Mladenov, N.: Dissolved organic matter photolysis in Canadian arctic thaw ponds, Environ. Res. Lett., 8, 035026, https://doi.org/10.1088/1748-9326/8/3/035026, 2013.

Le Breton, M., McGillen, M. R., Muller, J. B. A., Bacak, A., Shallcross, D. E., Xiao, P., Huey, L. G., Tanner, D., Coe, H., and Percival, C. J.: Airborne observations of formic acid using a chemical ionization mass spectrometer, Atmos. Meas. Tech., 5, 30293039, https://doi.org/10.5194/amt-5-3029-2012, 2012.

Leaitch, W. R., Sharma, S., Huang, L., Toom-Sauntry, D., Chivulescu, A., Macdonald, A. M., von Salzen, K., Pierce, J. R., Bertram, A. K., Schroder, J. C., Shantz, N. C., Chang, R. Y.-W., and Norman, A.-L.: Dimethyl sulfide control of the clean summertime Arctic aerosol and cloud, Elem. Sci. Anth., 1, 000017 , https://doi.org/10.12952/journal.elementa.000017, 2013.

Lee, B. H., Lopez-Hilfiker, F. D., Mohr, C., Kurtén, T., Worsnop, D. R., and Thornton, J. A.: An iodide-adduct HighResolution Time-of-Flight Chemical-Ionization Mass Spectrometer: Application to atmospheric inorganic and organic compounds, Environ. Sci. Technol., 48, 6309-6317, https://doi.org/10.1021/es500362a, 2014.

Legrand, M. and De Angelis, M.: Origins and variations of light carboxylic acids in polar precipitation, J. Geophys. Res.-Atmos., 100, 1445-1462, https://doi.org/10.1029/94JD02614, 1995.

Lelieveld, J. and Crutzen, P. J.: The role of clouds in tropospheric photochemistry, J. Atmos. Chem., 12, 229-267, https://doi.org/10.1007/BF00048075, 1991.

Li, S.-M., Barrie, L. A., and Sirois, A.: Biogenic sulfur aerosol in the Arctic troposphere: 2. Trends and seasonal variations, J. Geophys. Res.-Atmos., 98, 20623-20631, https://doi.org/10.1029/93JD02233, 1993.

Liggio, J., Moussa, S. G., Wentzell, J., Darlington, A., Liu, P., Leithead, A., Hayden, K., O’Brien, J., Mittermeier, R. L., Staebler, R., Wolde, M., and Li, S.-M.: Understanding the primary emissions and secondary formation of gaseous organic acids in the oil sands region of Alberta, Canada, Atmos. Chem. Phys., 17, 8411-8427, https://doi.org/10.5194/acp-17-8411-2017, 2017.
Lindwall, F., Schollert, M., Michelsen, A., Blok, D., and Rinnan, R.: Arctic summer warming causes four-fold higher tundra volatile emissions, J. Geophys. Res.-Biogeo., 895-902, https://doi.org/10.1002/2015JG003295, 2016.

Liu, J., Zhang, X., Parker, E. T., Veres, P. R., Roberts, J. M., de Gouw, J. A., Hayes, P. L., Jimenez, J. L., Murphy, J. G., Ellis, R. A., Huey, L. G., and Weber, R. J.: On the gasparticle partitioning of soluble organic aerosol in two urban atmospheres with contrasting emissions: 2. Gas and particle phase formic acid, J. Geophys. Res.-Atmos., 117, D00V21, https://doi.org/10.1029/2012JD017912, 2012.

Liu, N. and Treitz, P.: Modelling high arctic percent vegetation cover using field digital images and high resolution satellite data, Int. J. Appl. Earth Obs. Geoinf., 52, 445-456, https://doi.org/10.1016/j.jag.2016.06.023, 2016.

Long, C. N. and Shi, Y.: An automated quality assessment and control algorithm for surface radiation measurements, Open Atmos. Sci. J., 2, 23-37, https://doi.org/10.2174/1874282300802010023, 2008.

Long, C. N., Ackerman, T. P., Gaustad, K. L., and Cole, J. N. S.: Estimation of fractional sky cover from broadband shortwave radiometer measurements, J. Geophys. Res.-Atmos., 111, D11204, https://doi.org/10.1029/2005JD006475, 2006.

Macdonald, K. M., Sharma, S., Toom, D., Chivulescu, A., Hanna, S., Bertram, A. K., Platt, A., Elsasser, M., Huang, L., Tarasick, D., Chellman, N., McConnell, J. R., Bozem, H., Kunkel, D., Lei, Y. D., Evans, G. J., and Abbatt, J. P. D.: Observations of atmospheric chemical deposition to high Arctic snow, Atmos. Chem. Phys., 17, 5775-5788, https://doi.org/10.5194/acp17-5775-2017, 2017.

Meyer, T., Lei, Y. D., Muradi, I., and Wania, F.: Organic Contaminant Release from Melting Snow. 1. Influence of Chemical Partitioning, Environ. Sci. Technol., 43, 657-662, https://doi.org/10.1021/es8020217, 2009.

Millet, D. B., Baasandorj, M., Farmer, D. K., Thornton, J. A., Baumann, K., Brophy, P., Chaliyakunnel, S., de Gouw, J. A., Graus, M., Hu, L., Koss, A., Lee, B. H., Lopez-Hilfiker, F. D., Neuman, J. A., Paulot, F., Peischl, J., Pollack, I. B., Ryerson, T. B., Warneke, C., Williams, B. J., and Xu, J.: A large and ubiquitous source of atmospheric formic acid, Atmos. Chem. Phys., 15, 6283-6304, https://doi.org/10.5194/acp-15-6283-2015, 2015.

Molina, M. J., Ivanov, A. V., Trakhtenberg, S., and Molina, L. T.: Atmospheric evolution of organic aerosol, Geophys. Res. Lett., 31, L22104, https://doi.org/10.1029/2004GL020910, 2004.

Mungall, E. L., Abbatt, J. P. D., Wentzell, J. J. B., Lee, A. K. Y., Thomas, J. L., Blais, M., Gosselin, M., Miller, L. A., Papakyriakou, T., Willis, M. D., and Liggio, J.: Microlayer source of oxygenated volatile organic compounds in the summertime marine Arctic boundary layer, P. Natl. Acad. Sci. USA, 114, 6203-6208, https://doi.org/10.1073/pnas.1620571114, 2017.

Nielsen, C. S., Michelsen, A., Strobel, B. W., Wulff, K., Banyasz, I., and Elberling, B.: Correlations between substrate availability, dissolved $\mathrm{CH} 4$, and $\mathrm{CH}_{4}$ emissions in an arctic wetland subject to warming and plant removal, J. Geophys. Res.-Biogeo., 122, 645-660, https://doi.org/10.1002/2016JG003511, 2017.

Niinemets, U., Fares, S., Harley, P., and Jardine, K. J.: Bidirectional exchange of biogenic volatiles with vegetation: emission sources, reactions, breakdown and deposition, Plant, Cell Environ., 37, 1790-1809, https://doi.org/10.1111/pce.12322, 2014. 
Ohmura, A., Dutton, E. G., Forgan, B., Fröhlich, C., Gilgen, H., Hegner, H., Heimo, A., König-Langlo, G., McArthur, B., Müller, G., Philipona, R., Pinker, R., Whitlock, C. H., Dehne, K., and Wild, M.: Baseline Surface Radiation Network (BSRN/WCRP): New precision radiometry for climate research, B. Am. Meteorol. Soc., 79, 2115-2136, 1998.

Paulot, F., Wunch, D., Crounse, J. D., Toon, G. C., Millet, D. B., DeCarlo, P. F., Vigouroux, C., Deutscher, N. M., González Abad, G., Notholt, J., Warneke, T., Hannigan, J. W., Warneke, C., de Gouw, J. A., Dunlea, E. J., De Mazière, M., Griffith, D. W. T., Bernath, P., Jimenez, J. L., and Wennberg, P. O.: Importance of secondary sources in the atmospheric budgets of formic and acetic acids, Atmos. Chem. Phys., 11, 1989-2013, https://doi.org/10.5194/acp-11-1989-2011, 2011.

Persson, P. and Stone, R.: Evidence of forcing of Arctic regional climates by mesoscale processes, San Antonio, TX, 2007.

Rinnan, R., Steinke, M., Mcgenity, T., and Loreto, F.: Plant volatiles in extreme terrestrial and marine environments, Plant Cell Environ., 37, 1776-1789, https://doi.org/10.1111/pce.12320, 2014.

Sanhueza, E. and Andreae, M. O.: Emission of formic and acetic acids from tropical Savanna soils, Geophys. Res. Lett., 18, 17071710, https://doi.org/10.1029/91GL01565, 1991.

Schobesberger, S., Lopez-Hilfiker, F. D., Taipale, D., Millet, D. B., D’Ambro, E. L., Rantala, P., Mammarella, I., Zhou, P., Wolfe, G. M., Lee, B. H., Boy, M., and Thornton, J. A.: High upward fluxes of formic acid from a boreal forest canopy, Geophys. Res. Lett., 43, 9342-9351, https://doi.org/10.1002/2016GL069599, 2016.

Schollert, M., Burchard, S., Faubert, P., Michelsen, A., and Rinnan, R.: Biogenic volatile organic compound emissions in four vegetation types in high arctic Greenland, Polar Biol., 37, 237-249, https://doi.org/10.1007/s00300-013-1427-0, 2013.

Seidel, D. J., Ao, C. O., and Kun, L.: Estimating climatological planetary boundary layer heights from radiosonde observations: Comparison of methods and uncertainty analysis, J. Geophys. Res.-Atmos., 115, D16113, https://doi.org/10.1029/2009JD013680, 2010.

Seinfeld and Pandis, S. N.: Atmospheric Chemistry and Physics, John Wiley \& Sons Australia, Limited, 1998.

Sharma, S., Chan, E., Ishizawa, M., Toom-Sauntry, D., Gong, S. L., Li, S. M., Tarasick, D. W., Leaitch, W. R., Norman, A., Quinn, P. K., Bates, T. S., Levasseur, M., Barrie, L. A., and Maenhaut, W.: Influence of transport and ocean ice extent on biogenic aerosol sulfur in the Arctic atmosphere, J. Geophys. Res.Atmos., 117, D12209, https://doi.org/10.1029/2011JD017074, 2012.

Stavrakou, T., Müller, J.-F., Peeters, J., Razavi, A., Clarisse, L., Clerbaux, C., Coheur, P.-F., Hurtmans, D., De Mazière, M., Vigouroux, C., Deutscher, N. M., Griffith, D. W. T., Jones, N., and Paton-Walsh, C.: Satellite evidence for a large source of formic acid from boreal and tropical forests, Nat. Geosci., 5, 2630, https://doi.org/10.1038/ngeo1354, 2012.

Stohl, A.: Characteristics of atmospheric transport into the Arctic troposphere, J. Geophys. Res.-Atmos., 111, D11306, https://doi.org/10.1029/2005JD006888, 2006.

Stohl, A., Forster, C., Frank, A., Seibert, P., and Wotawa, G.: Technical note: The Lagrangian particle dispersion model FLEXPART version 6.2, Atmos. Chem. Phys., 5, 2461-2474, https://doi.org/10.5194/acp-5-2461-2005, 2005.
Ström, L., Tagesson, T., Mastepanov, M., and Christensen, T. R.: Presence of Eriophorum scheuchzeri enhances substrate availability and methane emission in an Arctic wetland, Soil Biol. Biochem., 45, 61-70, https://doi.org/10.1016/j.soilbio.2011.09.005, 2012.

Talbot, R. W., Beecher, K. M., Harriss, R. C., and Cofer, W. R.: Atmospheric geochemistry of formic and acetic acids at a midlatitude temperate site, J. Geophys. Res.-Atmos., 93, 1638-1652, https://doi.org/10.1029/JD093iD02p01638, 1988.

Talbot, R. W., Vijgen, A. S., and Harriss, R. C.: Soluble species in the Arctic summer troposphere: Acidic gases, aerosols, and precipitation, J. Geophys. Res.-Atmos., 97, 16531-16543, https://doi.org/10.1029/91JD00118, 1992.

Tang, S., LaDuke, G., Chien, W., and Frank, B. P.: Impacts of biodiesel blends on $\mathrm{PM}_{2.5}$, particle number and size distribution, and elemental/organic carbon from nonroad diesel generators, Fuel, 172, 11-19, https://doi.org/10.1016/j.fuel.2015.12.060, 2016.

Tarasick, D. W. and Bottenheim, J. W.: Surface ozone depletion episodes in the Arctic and Antarctic from historical ozonesonde records, Atmos. Chem. Phys., 2, 197-205, https://doi.org/10.5194/acp-2-197-2002, 2002.

Tjernström, M.: Is There a diurnal cycle in the summer cloudcapped Arctic boundary layer?, J. Atmos. Sci., 64, 3970-3986, https://doi.org/10.1175/2007JAS2257.1, 2007.

Vedel-Petersen, I., Schollert, M., Nymand, J., and Rinnan, R.: Volatile organic compound emission profiles of four common arctic plants, Atmos. Environ., 120, 117-126, https://doi.org/10.1016/j.atmosenv.2015.08.082, 2015.

Veres, P., Roberts, J. M., Burling, I. R., Warneke, C., de Gouw, J., and Yokelson, R. J.: Measurements of gas-phase inorganic and organic acids from biomass fires by negative-ion proton-transfer chemical-ionization mass spectrometry, J. Geophys. Res.Atmos., 115, D23302, https://doi.org/10.1029/2010JD014033, 2010.

Vet, R., Artz, R. S., Carou, S., Shaw, M., Ro, C.-U., Aas, W., Baker, A., Bowersox, V. C., Dentener, F., Galy-Lacaux, C., Hou, A., Pienaar, J. J., Gillett, R., Forti, M. C., Gromov, S., Hara, H., Khodzher, T., Mahowald, N. M., Nickovic, S., Rao, P. S. P., and Reid, N. W.: A global assessment of precipitation chemistry and deposition of sulfur, nitrogen, sea salt, base cations, organic acids, acidity and pH, and phosphorus, Atmos. Environ., 93, 3 100, https://doi.org/10.1016/j.atmosenv.2013.10.060, 2014.

Viatte, C., Strong, K., Walker, K. A., and Drummond, J. R.: Five years of $\mathrm{CO}, \mathrm{HCN}, \mathrm{C}_{2} \mathrm{H}_{6}, \mathrm{C}_{2} \mathrm{H}_{2}, \mathrm{CH}_{3} \mathrm{OH}, \mathrm{HCOOH}$ and $\mathrm{H}_{2} \mathrm{CO}$ total columns measured in the Canadian high Arctic, Atmos. Meas. Tech., 7, 1547-1570, https://doi.org/10.5194/amt-7-15472014, 2014.

Vlasenko, A., George, I. J., and Abbatt, J. P. D.: Formation of Volatile Organic Compounds in the Heterogeneous Oxidation of Condensed-Phase Organic Films by Gas-Phase OH, J. Phys. Chem. A, 112, 1552-1560, https://doi.org/10.1021/jp0772979, 2008.

von Kuhlmann, R.: A model for studies of tropospheric ozone and nonmethane hydrocarbons: Model evaluation of ozone-related species, J. Geophys. Res., 108, 4729, https://doi.org/10.1029/2002JD003348, 2003.

Wagner-Riddle, C., Hu, Q. C., van Bochove, E., and Jayasundara, S.: Linking nitrous oxide flux during spring thaw to nitrate deni- 
trification in the soil Profile, Soil Sci. Soc. Am. J., 72, 908-916, https://doi.org/10.2136/sssaj2007.0353, 2008.

Warneke, C., Karl, T., Judmaier, H., Hansel, A., Jordan, A., Lindinger, W., and Crutzen, P. J.: Acetone, methanol, and other partially oxidized volatile organic emissions from dead plant matter by abiological processes: Significance for atmospheric $\mathrm{HO}_{x}$ chemistry, Global Biogeochem. Cy., 13, 9-17, https://doi.org/10.1029/98GB02428, 1999.

Wentworth, G. R., Murphy, J. G., Gregoire, P. K., Cheyne, C. A. L., Tevlin, A. G., and Hems, R.: Soil-atmosphere exchange of ammonia in a non-fertilized grassland: measured emission potentials and inferred fluxes, Biogeosciences, 11, 5675-5686, https://doi.org/10.5194/bg-11-5675-2014, 2014.

Willis, M. D., Köllner, F., Burkart, J., Bozem, H., Thomas, J. L., Schneider, J., Aliabadi, A. A., Hoor, P. M., Schulz, H., Herber, A. B., Leaitch, W. R., and Abbatt, J. P. D.: Evidence for marine biogenic influence on summertime Arctic aerosol, Geophys. Res. Lett., 44, 6460-6470, https://doi.org/10.1002/2017GL073359, 2017.
Yuan, B., Veres, P. R., Warneke, C., Roberts, J. M., Gilman, J. B., Koss, A., Edwards, P. M., Graus, M., Kuster, W. C., Li, S.-M., Wild, R. J., Brown, S. S., Dubé, W. P., Lerner, B. M., Williams, E. J., Johnson, J. E., Quinn, P. K., Bates, T. S., Lefer, B., Hayes, P. L., Jimenez, J. L., Weber, R. J., Zamora, R., Ervens, B., Millet, D. B., Rappenglück, B., and de Gouw, J. A.: Investigation of secondary formation of formic acid: urban environment vs. oil and gas producing region, Atmos. Chem. Phys., 15, 1975-1993, https://doi.org/10.5194/acp-15-1975-2015, 2015. 